\title{
THE FUNCTION OF THE DUE PROCESS CLAUSE
}

\section{LEONARD G. RATNER $\dagger$}

One function of the American Constitution is to provide written evidence of the limitations upon official authority and majority control. Whether written or unwritten, restraints on democratic government necessarily reflect predominant community conceptions of the relationship between governor and governed. But unwritten restraints tend to be less discernible and less dependable; their protean contours more readily conform to current majority inclination, and enforcement responsibility, if assigned, connotes an indeterminate discretion to limit regulatory policy. Community cohesiveness is more effectively promoted by an authoritative document that provides an accepted frame of reference and an overt symbol of common goals.

The written word, fashioned in the mold of a particular time and place, is less flexible than unwritten tradition; yet the writing must communicate to successive generations standards responsive to changing community needs. Such communication is facilitated by the inherent ambiguity of language, an ambiguity resulting from tension between the sifting, organizing generality of words and the uniqueness of events. Resolution of that ambiguity varies with each communicatee's experience and with his perception of the social and psychological context that envelops communication. Constitutional phrases are construed and applied by each generation in the context of existing attitudes and needs. Continuity results from the generational overlap and from the indispensable role of past experience in resolving present problems.

Although they cannot alone define underlying goals or values, the ambiguous constitutional statements do not lack significance. They are starting points for thinking about governmental function. Together they outline a plan of government. They identify areas of community concern and indicate the direction of resolution. In this sense they suggest important community values that more fully emerge in the solution of specific problems ; ${ }^{1}$ they are constitutional sources of such values. By contrast, values not suggested by the language of the Constitution are necessarily derived from nonconstitutional, natural

$\doteqdot$ Professor of Law, University of Southern California. A.B. 1937, University of California (Los Angeles); J.D. 1940, University of California (Berkeley). Member, California Bar.

1 Values are discussed in the text at notes 157-62 infra. 
law sources; that is, from an appraisal of community structure, tradition, and needs. ${ }^{2}$

Perhaps the most ambiguous statement in the Constitution is the admonition of the fifth and fourteenth amendments that neither federal nor state government shall "deprive anv_person of life, liberty, or property without due process of law." 3 "Life. liberty, and property" encompass all human activity; "law" encompasses all governmentally enforced community values; and "due process" suggests inchoate restrictions on methods of enforcement

It has long since been demonstrated that the phrase "due process of law" is a variation of Magna Carta's "according to the law of the land," which restricted the enforcement procedures available to English monarchs. ${ }^{4}$ But for three quarters of a century the due process clause has been judicially employed as a constitutional reservoir of values to support a broad spectrum of limitations upon conduct-regulating as well as enforcement policies ${ }^{5}$ of state and national governments. ${ }^{6}$ The identifying characteristics of the favored values remain indistinct. The Supreme Court has not clearly delineated the constitutional function of the clause: the distinctive values that underlie it, the implications of those values, their significance to the constitutional plan, their relationship to other values, and the role of the judiciary in their implementation.

The clause is not necessarily either an authorization for judicial balancing of the individual's "natural rights" 7 against the social benefits of regulation, or no more than a recapitulation of important Bill of Rights protections, although such a polarity pervades recent

2 Natural law, as used herein, refers to societal, not transcendental, values. For a discussion of the several connotations of natural law see 19 ENCYCLOPEDIA AMERICANA 768-69 (1964); 11 ENCYCLOPEDIA OF Soctal SCIENCES 284 (1933).

3 U.S. CoNst. amend. XIV, §1: "[N]or shall any State deprive any person of life, liberty, or property, without due process of law. . " U.S. ConsT. amend. V: "[N] or shall any person . . . be deprived of life, liberty, or property, without due process of law. . .."

4 Corwin, The Doctrine of Due Process of Law Before the Civil War, 24 Harv. L. REv. 366, 368-70 (1911); see E. CoRwIn, LIBERTy AGatNST GOVERNMENT 90-91 (1948); McIlwain, Due Process of Law in Magna Carta, 14 Colum. L. Rev. 27 (1914).

5 Enforcement policies underlie the institutional procedures for resolving public and private disputes, including adjudication and ancillary seizure of person or property. See text accompanying note 76 infra. Conduct-regulating policies generally underlie the other governmental controls on behavior, not excluding taxes (which restrict consumption and investment) and spending (which promotes or controls individual activity). Policies that underlie the structure of governmental institutions may sometimes constitute a separate category. See text accompanying note 273 infra.

${ }^{6}$ See cases cited note 13 infra.

7 Natural rights, derived from natural law values, are tentative identifications of nonregulable individual activities. See note 2 supra and accompanying text. See also 11 Encyclopedia of Soctal Sctences 299 (1933). 
judicial pronouncements on "substantive" due process. 8 The broad view is not consistent with the constitutional plan of written limitations, nor with the role of the judiciary as interpreter of those limitations; the narrow view disregards the philosophy of government that pervades the plan. ${ }^{9}$ That philosophy, reflected by the ninth amendment's acknowledgment of residual rights as well as by the due process clause, suggests a social purpose limitation on government, requiring not public gain heavier than private detriment, but a regulatory purpose that reflects recognizable community values and a regulatory method that intrudes on individual choice no more than necessary to implement the purpose.

Such a due process limitation joins legislature and judiciary in a cooperative search for effective methods of accommodating regulatory goals with individual autonomy. The judiciary reviews the alignment of regulatory purpose with recognizable community values, the implementation of that purpose by the regulatory method, and the restrictiveness, effectiveness, and cost of formal and non-formal alternative methods. The limitation subjects state or federal government to constitutional restraints on the other when the values underlying a restriction on one government are implemented by application of that restriction to both. It denies social purpose to regulatory goals that contradict constitutional values. It confines implementation of useful goals to methods that minimize intrusion on constitutionally sheltered activity. It may perhaps be judicially applied to facilitate social testing of less intrusive methods. It prefers an accommodation of competing constitutional values to a subordination of the "lighter" one.

In addition, judicial litigation expertise and the context of "due process" suggest judicial authority to derive from the process of adjudication fair trial requisites not included in the Bill of Rights, a function resembling statutory interpretation and common law development. But constitutionally authorized fair trial values must be accommodated with other social purposes that sometimes underlie litigation procedures.

\section{Due Process and Fundamental Values: the Natural Rights LIMITATION}

The social compact postulate, that government as the agent of the governed may not deprive its principal of natural rights, ${ }^{10}$ led the United States Supreme Court and many state courts to the early position that all governmental authority is limited by principles

8 The due process limitation on conduct-regulating policy is commonly referred to as "substantive." See note 4 supra; notes 14-29 infra and accompanying text.

$\checkmark$ See text preceding note 129 infra.

10 See notes 2,7 supra. 
judicially derived from the nature of society. ${ }^{11}$ The judicial power thus asserted was no less than the authority to articulate and enforce limitations on the structure of American democracy free from legislative correction and constitutional restraint. ${ }^{12}$ But the inconsistency of such judicial discretion with the constitutional plan of written restraints led the courts to perceive the due process clauses of state and federal constitutions as the embodiment of natural law limitations upon governmental policy. ${ }^{13}$

Many judicially developed due process limitations have reflected values underlying other constitutional provisions, such as the predictability-antiretroactivity values implicit in the impairment of contract, eminent domain, ex post facto, and bill of attainder clauses. ${ }^{14}$ First amendment speech values are in fact reflected by decisions enforcing a due process natural right to conduct or attend private schools and to teach or be taught foreign languages. ${ }^{15}$ But nonconstitutional sources have generated such due process natural rights as protection of economic bargaining power, labeled "freedom of contract," 16 and

11 See Calder v. Bull, 3 U.S. ( 3 Dall.) 386 (1798) ; Fletcher v. Peck, 10 U.S. (6 Cranch) 87 (1810); Terrett v. Taylor, 13 U.S. (9 Cranch) 43 (1815); E. CoRWIN, LIBERTY AGAINST GovernMENT 10-67 (1948) ; Corwin, The "Higher Law" Background of American Constitutional Laze, 42 HARv. L. REv. 365, 381-409 (1929); Corwin, The Basic Doctrine of American Constitutional Law, 12 MICE. L. REv. 247 (1914).

12 See authorities cited note 11 supra.

13 See Adair v. United States, 208 U.S. 161 (1908); Allgeyer v. Louisiana, 165 U.S. 578 (1897) ; Missouri Pac. Ry. v. Nebraska, 164 U.S. 403 (1896); Mugler v. Kansas, 123 U.S. 623 (1887) ; Wynhammer v. People, 13 N.Y. 378 (1856) (dictum); E. Corwin, Liberty Against Governarent 89, 103-15 (1948); Corwin, supra note 4, 24 HARV. L. REV. pts. 1 \& 2,366, 460.

14 See FHA v. The Darlington, Inc., 358 U.S. 84 (1958) ; Perry v. United States, 294 U.S. 330 (1935); Lynch v. United States, 292 U.S. 571 (1934); Coolidge v. Long, 282 U.S. 582 (1931); Nichols v. Coolidge, 274 U.S. 531 (1927) ; Pennsylvania Coal Co. v. Mahon, 260 U.S.S 393 (1922) ; Ettor v. City of Tacoma, 228 U.S. 148 (1913) ; Smyth v. Ames, 169 U.S. 466 (1898) ; Chicago B. \& Q. R.R. v. Chicago, 166 U.S. 226 (1897); Railroad Commission Cases, 116 U.S. 307 (1886); Martin v. Mott, 25 U.S. (12 Wheat.) 19 (1827); Wynhammer v. People, 13 N.Y. 378 (1856); Taylor v. Porter, 4 Hill 140 (N.Y. 1843); North Carolina v. Foy, 2 Hayw. 310 (N.C. 1804); E. Corwin, supra note 11; The FEDERALIST No. 44, at 301 (Cooke ed. 1961) (J. Madison): "Bills of attainder, ex-post-facto laws, and laws impairing the obligation of contracts, are contrary to the first principles of the social compact . " $;$. WARREN, THE MAKING of THE CoNSTITUTION 552-56 (1928); Greenblatt, Judicial Limitations on Retroactive Civil Legislation, 51 Nw. L. Rev. 540 (1956); Hochman, The Supreme Contrt and the Constitutionality of Retroactive Legislation, 73 HARv. L. REv. 692 (1960); Slawson, Constitutional and Legislative Considerations in Retroactive Lawmaking, 48 CALIF. L. REv. 216 (1960); Smith, Retroactive Laws and Vested Rights, 5 Tex. L. Rev. 231 (1927); cf. Missouri Pac. Ry. v. Nebraska, 164 U.S. 403 (1896); Satterlee v. Matthewson, 27 U.S. (2 Pet.) 380, 681, 685-86 (1829).

15 See Farrington v. Tokushige, 273 U.S. 284 (1927); Pierce v. Society of Sisters, 286 U.S. 510 (1925) ; Meyer v. Nebraska, 262 U.S. 390 (1923).

16 Allgeyer v. Louisiana, 165 U.S. 578 (1897); Lochner v. New York, 198 U.S. 45 (1905); Adair v. United States, 208 U.S. 161 (1908); Coppage v. Kansas, 236 U.S. 1 (1915); Adams v. Tanner, 244 U.S. 590 (1917) ; Adkins v. Children's Hospital, 261 U.S. 525 (1923); Tyson \& Brother v. Banton, 273 U.S. 418 (1927); Ribnik v. McBride, 277 U.S. 350 (1928); Williams v. Standard Oil Co., 278 U.S. 235 (1929); New State Ice Co. v. Liebmann, 285 U.S. 262 (1932); Morehead v. New York ex rel. Tipaldo, 298 U.S. 587 (1936). 
enforcement of contracts in accordance with the law of the territory where "made." 17

The Supreme Court has not abandoned the position that the due process clause empowers the judiciary to impose nonconstitutional, natural law limitations upon the conduct-regulating and enforcement authority of federal and state governments. After concluding that impairment of the sanctified freedom of contract value could sometimes be "outweighed" by the social benefits ensuing from exercise of the "police power," 18 the Court moved on to divest that value of its privileged constitutional position, ${ }^{19}$ and repudiated territoriality as a constitutionally compelled choice-of-law standard. ${ }^{20}$ The cases marking the course of the desanctification contain strong language indicating that due process limitations on conduct-regulating authority were to be derived only from the Constitution and no longer from nonconstitutional sources.

[T] he only constitutional . . . restraints which respondents have suggested for the invalidation of legislation [controlling employment agency charges] are those notions of public policy embedded in earlier decisions of this Court but which, as Mr. Justice Holmes long admonished, should not be read into the Constitution,

said Justice Douglas for the entire Court in Olsen $v$. Nebraska; ${ }^{21}$

[s] ince they do not find expression in the Constitution, we cannot give them continuing vitality as standards by which the constitutionality of the economic and social programs of the states is to be determined. ${ }^{22}$

17 See Allgeyer v. Louisiana, 165 U.S. 578 (1897); New York Life Ins. Co. v. Dodge, 246 U.S. 357 (1918) ; Mutual Life Ins. Co. v. Liebling, 259 U.S. 209 (1922); Hartford Accident \& Indem. Co. v. Delta \& Pine Land Co., 292 U.S. 143 (1934).

18 First, when the regulation concerned business "clothed with a public interest"; then, when it concerned any economic enterprise. See Munn v. Illinois, 94 U.S. 113 (1876). See also Nebbia v. New York, 291 U.S. 502 (1934); Wolff Packing Co. v. Industrial Court, 262 U.S. 522 (1923). For a discussion of police power, see the text at notes $132-33$ infra.

19 West Coast Hotel Co. v. Parrish, 300 U.S. 379 (1937); United States v. Darby, 312 U.S. 100 (1941); Olsen v. Nebraska ex rel. Western Reference \& Bond Ass'n, 313 U.S. 236 (1941) ; Lincoln Federal Labor Union v. Northwestern Iron \& Metal Co., 335 U.S. 525 (1949) ; Day-Brite Lighting, Inc. v. Missouri, 342 U.S. 421 (1952); see Hetherington, State Economic Regulation and Substantive Due Process of Law, 53 Nw. U.L. REv. 13, 226 (1958).

20 Hoopeston Canning Co. v. Cullen, 318 U.S. 313 (1943) ; Watson v. Employers Liability Assurance Corp., 348 U.S. 66 (1954).

21 Olsen v. Nebraska ex rel. Western Reference \& Bond Ass'n, 313 U.S. 236, 246-47 (1941).

22 Id. at 247 (emphasis added). 
Upon upholding a state right-to-work law in Lincoln Federal Labor Union v. Northwestern Iron \& Metal Co., ${ }^{23}$ Justice Black emphasized for the majority that

states have power to legislate against what are found to be injurious practices in their internal commercial and business affairs, so long as their laws do not run afoul of some specific federal constitutional prohibition, or of some valid federal law. ${ }^{24}$

But while demoting freedom of contract, the Court has reiterated its authority to derive more attractive due process values from nonconstitutional sources.

If due process bars Congress from enactments that shock the sense of fair play-which is the essence of due processone is entitled to ask whether it is not beyond the power of Congress to deport an alien who was duped into joining the Communist Party .... [a]nd this because deportation may . . . deprive a man "of all that makes life worth living."

wrote Justice Frankfurter for a majority, in Galvan v. Press, ${ }^{25}$ that nevertheless upheld the deportation because the unlimited "political discretion" of Congress to deport aliens "has become . . . imbedded in the legislative and judicial tissues of our body politic . . . ."

[T] he right to travel is a part of the "liberty" of which the citizen cannot be deprived without the due process of law ... . Freedom of movement . . . was a part of our heritage [and] is basic in our scheme of values,

said the Court in Kent v. Dulles, ${ }^{26}$ invalidating, on statutory grounds, the denial of passports to Communists. The statement was quoted in Aptheker $v$. Secretary of State ${ }^{27}$ to support the invalidation on due process grounds of a statute authorizing revocation of Communists' passports. Justice Black rejected the "constitutional liberty to travel abroad" and concurred in Aptheker on the ground that the statutory scheme amounted to a bill of attainder, a denial of jury trial, and an impairment of free speech. ${ }^{28}$

23335 U.S. 525 (1949).

$24 I d$. at 536.

25347 U.S. 522,530 (1954).

26357 U.S. 116, 125-26 (1958) (Douglas, J.).

27378 U.S. 500, 505-06 (1964) (Goldberg, J.).

28378 U.S. 500, 518 (1964). But cf. Justice Black's acceptance of the majority opinion in Kent v. Dulles, 357 U.S. 116 (1958). 
These statutes [forbidding interracial marriage] . . . deprive the Lovings [not only of equal protection of the laws but also] of liberty without due process of law .... The freedom to marry has long been recognized as one of the vital personal rights essential to the orderly pursuit of happiness by free men. Marriage is one of the "basic civil rights of man," fundamental to our very existence and survival,

recently declared Chief Justice Warren for eight justices in Loving v. Virginia. ${ }^{29}$

Reliable evidence forcibly retrieved from the stomach of a defendant was excluded from a state criminal trial on due process grounds in Rochin v. California ${ }^{30}$ because

[t] his is conduct that shocks the conscience... .

. . Due process of law, as a historic and generative principle, precludes defining, and thereby confining, these standards of conduct more precisely than to say that convictions cannot be brought about by methods that offend "a sense of justice." 31

Justices Black and Douglas rejected the "sense of justice" standard in favor of a due process limitation on state authority derived from the self-incrimination values reflected by the fifth amendment's limitation on federal authority. ${ }^{32}$

A majority of the Court has persistently maintained that many Bill of Rights limitations upon federal authority are also fourteenth amendment due process limitations on state authority not because they

29388 U.S. 1, 12 (1967). Justice Black's concurrence in this language appears inconsistent with his long-expressed opposition to natural rights as a source of due process limitations. See Griswold v. Connecticut, 381 U.S. 479, 507 (1965) (dissenting opinion); Aptheker v. Secretary of State, 378 U.S. 500, 517 (1964) (concurring opinion); Rochin v. California, 342 U.S. 165, 174 (1952) (concurring opinion); Adamson v. California, 332 U.S. 46, 68 (1947) (dissenting opinion).

30342 U.S. 165 (1952).

31 Id. at 172-73 (Frankfurter, J.). The Court went on to say :

Use of involuntary verbal confessions in State criminal trials is constitutionally obnoxious not only because of their unreliability. They are inadmissible under the Due Process Clause even thongh statements contained in them may be independently. established as true. Coerced confessions offend the community's sense of fair play and decency.

Id. at 173 (emphasis added). See also Blackburn v. Alabama, 361 U.S. 199 (1960); Rodgers v. Richmond, 305 U.S. 534 (1961). More recently the Court has concluded that all of the search and seizure and self-incrimination values of the fourth and fifth amendments are due process values under the fourteenth amendment, thereby making the Rochin standard superfluous when those values are present. Malloy v. Hogan, 378 U.S. 1 (1964) ; Mapp v. Ohio, 367 U.S. 643 (1961). But the "sense of justice" standard has been reaffirmed in Schmerber v. California, 384 U.S. 757 (1966) (dictum).

32342 U.S. 165, 174, 177 (concurring opinions). 
are in the Bill of Rights but because they are "principle[s] of justice so rooted in the tradition and conscience of our people as to be ranked as fundamental" and therefore "implicit in the concept of ordered liberty," ${ }^{33}$ or are "basic in our system of jurisprudence," ${ }^{34}$ the latest formulation being "fundamental to the American scheme of justice . necessary to an Anglo-American regime of ordered liberty." 35 Most of the majority view the fourteenth amendment as "absorbing" or "incorporating" the fundamental limitations, implying perhaps that a presumption of fundamentalness arises from specification in the Bill of Rights. ${ }^{38}$ A few led by Justice Harlan insist that due process limitations are identified not by incorporation or absorption but solely by the Court's perception of their fundamental nature, concomitant mention in the Bill of Rights presumably being a not-unexpected coincidence. $^{37}$

The difference in the two views is not entirely academic. In recent cases the selective incorporators have expanded the fundamental limitation category and extended to the states every restraint on federal authority derived from such limitations. ${ }^{38}$ The nonincorporators are more reluctant to discern fundamentalness, and cling to the

33 Palko v. Connecticut, 302 U.S. 319, 325 (1937) (Cardozo, J.), quoting Snyder v. Massachusetts, 291 U.S. 97, 105 (1934). See Kadish, Methodology and Criteria in Due Process Adjudication-A Survey and Criticism, 66 Yale L.J. 319 (1958). See also Twining v. New Jersey, 211 U.S. 78, 106 (1908); Hurtado v. California, 110 U.S. 516,535 (1884).

34 In re Oliver, 333 U.S. 257, 273 (1948).

35 Duncan v. Louisiana, 88 S.Ct. 1444, 1447, 1448 n.14 (1968).

36 Cases cited note 38 infra; Cohen v. Hurley, 366 U.S. 117 (1961); id. at 154 (Brennan, J., dissenting); Rochin v. California, 342 U.S. 165 (1953); Wolf v. Colorado, 338 U.S. 25 (1949); Adamson v. California, 332 U.S. 46 (1947); Palko v. Connecticut, 302 U.S. 319 (1937) ; De Jonge v. Oregon, 299 U.S. 353 (1937) ; Gitlow v. New York, 268 U.S. 562 (1925) ; Henkin, Selective Incorporation in the Fourteenth Amendment, 73 Y ALE L.J. 74 (1963).

37 Duncan v. Louisiana, 88 S.Ct. 1444,1460 (1968) (Harlan \& Stewart, JJ., dissenting); Klopfer v. North Carolina, 386 U.S. 213, 226 (1967) (Harlan, J., concurring); Griswold v. Connecticut, 381 U.S. 479, 499 (1965) (Harlan \& White, JJ., concurring); Griffin v. California, 380 U.S. 609, 615 (1965) (Harlan, J., concurring); Pointer v. Texas, 380 U.S. 400, 408 (1964) (Harlan \& Stewart, JJ., concurring)'; Malloy v. Hogan, 378 U.S. 1, 14 (1964) (Harlan \& Clark, JJ., dissenting); see Murphy v. Waterfront Commission, 378 U.S. 52, 80 (1964) (Harlan \& Clark, JJ., concurring) ; Twining v. New Jersey, 211 U.S. 78 (1911); cf. Mapp v. Ohio, 367 UU.S. 643, 672 (1961) (Harlan, Frankfurter, \& Whittaker, JJ., dissenting).

38 Duncan v. Louisiana, 88 S.Ct. 1444 (1968) (sixth amendment jury trial); Klopfer v. North Carolina, 386 U.S. 213 (1967) (sixth amendment speedy trial); Spevack v. Klein, 385 U.S. 511 (1967) (application of fifth amendment self-incrimination privilege to disbarment of lawyers); Garrity v. New Jersey, 385 U.S. 493 (1967) (application of fifth amendment self-incrimination privilege to discharge of public employees); Griffin v. California, 380 U.S. 609 (1965) (application of fifth amendment self-incrimination privilege to prosecutor comment on failure of accused to testify); Pointer v. Texas, 380 U.S. 400 (1965) (sixth amendment confrontation of witnesses); Malloy v. Hogan, 378 U.S. 1 (1964) (fifth amendment self-incrimination privilege); Gideon v. Wainwright, 372 U.S. 335 (1963) (sixth amendment assistance of counsel in non-capital cases); Mapp v. Ohio, 367 U.S. 643 (1961) (exclusion of evidence obtained by fourth amendment unreasonable search and seizure). 
earlier view that due process tolerates non-fundamental state encroachments on fundamental Bill of Rights limitations although similar federal encroachments are proscribed. ${ }^{39}$

But the selective incorporators neither assert that every Bill of Rights provision is automatically absorbed by the fourteenth amendment nor disclaim authority to derive due process values from nonconstitutional sources. Explicitly or implicitly, they indicate that the extended protections are fundamental and that such fundamental protections must similarly limit federal and state authority. ${ }^{40}$

A minority led by Justice Black perceives fourteenth amendment incorporation of the entire Bill of Rights ${ }^{41}$ but has divided over the derivation of additional due process protections from nonconstitutional sources. Justices Murphy and Rutledge favored such derivation. ${ }^{42}$ Justices Black and Douglas oppose it, ${ }^{43}$ but have accepted the "fundamental limitation" premise when writing for a majority in support of extended Bill of Rights applications. ${ }^{44}$

Judicial authority to identify fundamental guarantees in the Bill of Rights does not negative judicial authority to derive fundamental guarantees from other sources. After the search and seizure and selfincrimination values of the fourth and fifth amendments had been recognized as fourteenth amendment due process values, a majority in Schmerber $v$. California decided that police-supervised extraction of blood from an objecting patient to prove drunkenness impaired neither search and seizure nor self-incrimination values, "and did not offend "that "sense of justice" ' of which we spoke in Rochin . . . ." $4 \bar{\sigma}$

39 See cases cited note 37 supra. See also Duncan v. Louisiana, 88 C.St. 1444, 1459 (1968) (Fortas, J., concurring); cases cited note 36 supra.

40 See cases cited note 38 supra. Justice Brennan's opinion in Malloy v. Hogan, 378 U.S. 1 (1964), comes close to adopting a rationale of total incorporation but does not do so and is illuminated by his dissenting opinion in Cohen v. Hurley, 366 U.S. 117,154 (1961).

41 Cohen v. Hurley, 366 U.S. 117, 150 (1961) (Black \& Douglas, JJ., dissenting) ; Irvine v. California, 347 U.S. 128, 139 (1954) (Black \& Douglas, JJ., dissenting); Rochin v. California, 342 U.S. 165, 174, 177 (1952) (Black, J., and Douglas, J., concurring); Wolf v. Colorado, 338 U.S. 25, 39, 40, 41 (1949) (Black, J., concurring; Rutledge, Murphy, \& Douglas, JJ., dissenting) ; Adamson v. California, 332 U.S. 46, 68,123 (1947) (Black, Douglas, Murphy, \& Rutledge, JJ., dissenting).

42 See the dissents of Justices Murphy and Rutledge cited note 41 supra.

43 See the dissents and concurrences of Justices Black and Douglas cited note 41 supra.

44 Spevack v. Klein, 385 U.S. 511 (1967) (majority opinion by Douglas, J.; Black, J., concurring) ; Garrity v. New Jersey, 385 U.S. 493 (1967) (majority opinion by Douglas, J.; Black, J., concurring); Griffin v. California, 380 U.S. 609 (1965) (majority opinion by Douglas, J.; Black, J., concurring); Pointer v. Texas, 380 U.S. 400 (1965) (majority opinion by Black, J.; Douglas, J., concurring); Gideon v. Wainwright, 372 U.S. 335 (1963) (majority opinion by Black, J.; Douglas, J., concurring); see Klopfer v. North Carolina, 386 U.S. 213 (1967) (majority opinion by Warren, C.J.; Douglas \& Black, JJ., concurring).

45384 U.S. 757, 760 (1966). 
The terms sense of justice, fundamental principles, rights fundamental to the American scheme of justice, traditions and conscience of the people, basic civil rights, fair play, concept of ordered liberty, decency, and heritage, are modern designations for the natural rights of man. They are labels, not standards for decision, suggesting longrange community values perceived by the judiciary but not necessarily reflected by the Constitution. Values thus labeled have become constitutional limitations on governmental authority, apparently to be balanced against the social benefits of regulation.

\section{Modern Dissonance: The Griszold Cacophony}

The obbligato of uncertainty concerning the nature of the judicial due process function became strident when, in Griswold $v$. Connecti$c u t,{ }^{48}$ the Supreme Court invalidated on due process grounds the application to married couples of a statute that prohibited use of contraceptives "for the purpose of preventing conception" but not of preventing disease. ${ }^{47}$ The defendants, a physician and the Director of the Planned Parenthood League, had aided and abetted violation of the statute by prescribing contraceptives for married couples at a birth control clinic. ${ }^{48}$ A majority of the Court agreed that the contraceptive ban impaired a fundamental due process value, the privacy of the marital relationship, but differed as to the source of that value.

Justices Douglas and Clark ${ }^{49}$ located it in a constitutional "zone of privacy" formed by "penumbras" emanating from the first, third, fourth, and fifth amendments ${ }^{50}$ and from the ninth amendment's declaration that "the enumeration in the Constitution of certain rights

48381 U.S. 479 (1965).

47 Conn. Gen. Stat. Ann. §53-32 (1958): "Any person who uses any drug, medicinal article or instrument for the purpose of preventing conception shall be fined not less than fifty dollars or imprisoned not less than sixty days nor more than one year or be both fined and imprisoned."

48 Conn. Gen. Stat. AnN. \$ 54-196 (1958): "Any person who assists, abets, counsels, causes, hires or commands another to commit any offense may be prosecuted and punished as if he were the principal offender."

Defendants were accorded standing to assert the constitutional claims of their patients because "the accessory should have standing to assert that the offense which he is charged with assisting is not, or cannot constitutionally be, a crime," 381 U.S. at 481 , and because "the rights of husband and wife, pressed here, are likely to be considered in a suit involving those who have this kind of confidential relation to them." Id. But cf. Tileston v. Ullman, 318 U.S. 44 (1943).

49 Justice Douglas delivered the opinion of the Court, in which Justice Clark concurred. Justices Goldberg and Brennan, and Chief Justice Warren, stated in their concurring opinion that they joined in the opinion and judgment of the Court. 381 U.S. at 486 .

50 The first amendment's protection of free speech and association, the third amendment's proscription of uninvited peacetime quartering of soldiers, the fourth amendment's protection against unreasonable searches and seizures, and the fifth amendment's protection against compulsory self-incrimination. 381 U.S. at 484. 
shall not be construed to deny or disparage others retained by the people." 51

Justice Goldberg and two others agreed that marital privacy is a fundamental due process value "within the protected penumbra of specific guarantees of the Bill of Rights" but reiterated that "the [due process] concept of liberty . . . is not confined to the specific terms of the Bill of Rights" 52 and stressed the relevance of the ninth amendment's preservation of rights not elsewhere enumerated, quoting in explanation of the purpose of that amendment James Madison's statement to Congress :

It has been objected also against a bill of rights, that, by enumerating particular exceptions to the grant of power, it would disparage those rights which were not placed in that enumeration; and it might follow by implication, that those rights which were not singled out, were intended to be assigned into the hands of the General Government, and were consequently insecure. . . . I conceive that it may be guarded against. I have attempted it . . . [in] the last clause of the fourth resolution [the ninth amendment]. ${ }^{53}$

Justice Goldberg perhaps intended no more than to support the penumbra concept by identifying the ninth amendment as a kind of "necessary and proper clause" of the Bill of Rights, authorizing the Court to protect constitutional values implicitly but not explicitly designated. He said:

Nor do I mean to state that the Ninth Amendment constitutes an independent source of rights protected from infringement by either the States or the Federal Government. Rather, the Ninth Amendment shows a belief of the Constitution's authors that fundamental rights exist that are not expressly enumerated in the first eight amendments ... . ${ }^{5 \pm}$

But his later assertion that

[t] he right of privacy in the marital relation is fundamental and basic - a personal right "retained by the people" within the meaning of the Ninth Amendment . . . protected by the Fourteenth Amendment from infringement by the States ${ }^{55}$

51 U.S. Const. amend. IX; see 381 U.S. at 484.

82381 U.S. at 486 (Goldberg, J., Warren, C.J., \& Brennan, J., concurring).

53 Id. at $489-90$; see $2 \mathrm{~J}$. Story, Commentaries on the Constitution of the UNITED STATES 626-27, 651 (5th ed. 1891).

54381 U.S. at 492 (emphasis added).

55 Id. at 499. 
implies that the ninth amendment and the due process clause, taken together, permit the Court to identify fundamental values not derived from other provisions of the Constitution..$^{56}$

Justice Harlan, concurring, had no doubt that the Court properly could identify and enforce a fundamental marital privacy value without deriving it from the Bill of Rights. He rejected the view that "the Due Process Clause of the Fourteenth Amendment does not touch this Connecticut statute unless the enactment is found to violate some right assured by the letter or penumbra of the Bill of Rights," ${ }^{57}$ and declared:

While the relevant inquiry may be aided by resort to one or more of the provisions of the Bill of Rights, it is not dependent on them or any of their radiations. The Due Process Clause of the Fourteenth Amendment stands, in my opinion, on its own bottom. ${ }^{68}$

And Justice White, also concurring, had no difficulty in discerning, without resort to a constitutional source, that the right of marital intimacy, along with "the right 'to marry, establish a home, and bring up children,' " is "among 'the basic civil liberties of man" " and entitled to fourteenth amendment protection against regulation in the absence of "substantial justification" by the state..$^{59}$

On the other hand, Justices Black and Stewart in dissent had no doubt that the Constitution is the only proper source of fundamental due process values, and they could discern no express or implied constitutional recognition of the marital privacy value. Said Justice Black:

I like my privacy as well as the next one, but I am nevertheless compelled to admit that government has a right to invade it unless prohibited by some specific constitutional provision. . .

I do not believe that we are granted power by the Due Process Clause . . . to measure constitutionality by our belief that legislation is arbitrary, capricious or unreasonable, or accomplishes no justifiable purpose, or is offensive to our own notions of "civilized standards of conduct." 80

66 The opinion further states:

The language and history of the Ninth Amendment reveal that the Framers of the Constitution believed that there are additional fundamental rights, protected from governmental infringement, which exist alongside those fundamental rights specifically mentioned in the first eight constitutional amendments.

Id. at 488 .

57 Id. at 499.

$58 \mathrm{Id}$. at 500 .

68 Id. at 502.

$60 \mathrm{Id}$. at $510-13$. 
The ninth amendment, he said,

was passed, not to broaden the powers of this Court or any other department of "the General Government," but . . . to assure the people that the Constitution in all its provisions was intended to limit the Federal Government to the powers granted expressly or by necessary implication. ${ }^{61}$

Justice Stewart added:

[W] ]ere told that the Connecticut law does not "conform to current community standards." But it is not the function of this Court to decide cases on the basis of community standards. We are here to decide cases "agreeably to the Constitution and laws of the United States."

Thus, two members of the Court firmly adhered to the view that due process limitations on conduct-regulating authority must be drawn from constitutional sources; ${ }^{63}$ two members apparently took that view; ${ }^{64}$ two members firmly adhered to the opposite view; ${ }^{65}$ and three members apparently took the opposite view. ${ }^{68}$

\section{The Judicial Role: Limitations on Conducr-Regulating Policy}

The scope of judicial authority under the due process clause and the ninth amendment to formulate limitations on federal and state conduct-regulating policies ${ }^{67}$ turns upon the role of the judiciary in implementing the constitutional plan.

Common law development involves judicial identification of community goals or values and formulation of a dispute-resolving doctrine that most effectively implements them. But such identification and formulation are subject to prospective legislative correction.

Interpretation of a statute involves identification of its social function, called statutory purpose. The court seeks the dispute resolution that will best implement the goals underlying a relevant statutory statement. Effective discernment of statutory purpose requires appraisal of the inevitably ambiguous language in the context of the entire statute, its legislative history, the social setting in which it was enacted, the social problem it was designed to resolve, and the role

61 Id. at 520 .

62 Id. at 530.

63 Black \& Stewart, JJ.

64 Douglas \& Clark, JJ.

65 Harlan \& White, JJ.

66 Goldberg \& Brennan, JJ., \& Warren, C.J.

67 See note 5 supra. 
it has acquired in the implementation of total community policy. ${ }^{68}$ If such appraisal discloses tenable, alternative purposes, the court necessarily chooses the one that in its judgment best accommodates community needs. But the court's interpretation of the statute is always subject to prospective legislative correction.

Interpreting the broadly-phrased constitutional limitations on government is an especially creative function that requires identification of the long-range goals of American democracy reflected by each limitation and illumination of their significance in the resolution of particular disputes. The context of constitutional communication includes the total constitutional plan, the enactment proceedings, the problems of governmental structure that evoked the limitation, its accretion of implications in response to changing social conditions, and its acquired function in the network of existing community arrangements.

In this role, however, the Court is not subordinate to any other governmental institution. ${ }^{69}$ Constitutional limitations are most effective when enforced by an agency other than the one limited. Officials who ultimately define the limits of their own power can disregard those limits. ${ }^{70}$ The electorate, ordinarily concerned with more immediate issues, is unlikely to provide political enforcement of protections claimed by a minority. An election campaign is not usually an effective mechanism for persuading voters that a majority-approved policy will in the long run undermine important goals of American democracy.

Enforcement of those protections is entrusted by the Constitution to the "least dangerous branch" of government: ${ }^{71}$ a tribunal, insulated

68 See H. Hart \& A. Sachs, The Legal Process 1144-1241 (Tent. ed. 1958); P. MIshrin \& C. Morris, ON LAw IN Courts 318-513 (1965); Bishin, The Laze Finders: An Essay in Statutory Interpretation, 38 S. CAI. L. REv. 1 (1965); Fuller, Positivisin and Fidelity to Law-A Reply to Professor Hart, 71 Harv. L. Rev. 630 (1958).

69 Judicial authority to declare acts of Congress constitutionally unenforceable can no longer be seriously doubted, if, indeed, it ever could. See 1 RECORDS OF THE FEDERAL Conventron 21, 97, 108-10, 124, 138-40 (M. Farrand ed. 1911) ; 2 id. at 73-80, 293-98, 391, 589; A. Bickel, The Least Dangerous Branch 1-33 (1962); E. Corwin, The Doctrine of Judicial Review 41-45 (1914); H. M. HART \& H. WeChSLER, The Federal Courts and the Federal System 14-16, 92-95 (1953); A. McLaughitn, The Courts, the Constitution, and Parties 30-107 (1912); C. Warren, The Making of the Constitution 245, 248, 317-24 (1928); 1 C. Warren, The Supreme Court in United States Hrstory 206-65 (1922); Corwin, Marbury v. Madison and the Doctrine of Judicial Review, 12 MTCH. L. REv. 538 (1914); Rostow, The Democratic Character of Judicial Revieze, 66 HARv. L. REv. 193 (1952) ; Thayer, The Origin and Scope of the American Doctrine of Constitutional Law, 7 HARv. L. REv. 129 (1893); Wechsler, Toward Nentral Principles of Constitutional Law, 73

Harv. L. Rev. 1, 2-9 (1959). But see C. Beard \& M. Beard, The Rise of AMrerican CIVILIZATION 322-24 (1927); L. Boudin, GovernMent BY THE JUdiciary 102-04 (1932); M. Cohen, The Faith of a Lmberal 178-80, 182-85, 192 (1946); L. Hand, The Bill of Rights 10-15 (1958).

70 See Marbury v. Madison, 5 U.S. (1 Cranch) 137 (1803).

71 A. Bickes, The Least Dangerous Branch (1962). 
from direct political pressures, that has the power of neither purse, sword, nor administrative control; with authority only to decide disputes between contending parties; whose orders are dependent upon executive enforcement; whose size is subject to legislative variation; whose process of decision is reasoned analysis; and whose members are restrained by a long-standing professional tradition. ${ }^{72}$ But these restraints do not annul the extensive control over governmental function implicit in judicial authority to enforce the Constitution and to construe the scope of that authority. Coupled with natural law limitations, such control concentrates in a nonelected elite sweeping discretion to negate legislative policy.

The constitutional plan of written limitations confines the exercise of judicial discretion to a frame of reference approved by the community. The divisiveness of majority-minority dispute is ameliorated when resolution is based upon a declaration of values accepted as authoritative by both groups. Constitutional decisions derived from nonconstitutional values vitiate the cohesiveness engendered by the Constitution as a symbol of shared purposes. ${ }^{73}$

Because the Supreme Court lacks both an .electoral constituency and the power ultimately to enforce its own orders, acceptance of its constitutional interpretations is dependent upon the respect accorded its institutional position and the persuasiveness of the reasons given for its decisions. ${ }^{74}$ The traditional deference accorded the Constitution and the Court as its interpreter may induce in a disagreeing or uncertain majority at least tentative acceptance of controversial decisions that rest upon constitutionally indicated values. (In the long run the majority must be persuaded by discussion and experience that a particular constitutional interpretation preserves long-range community goals. When the majority is not so persuaded, that interpretation is likely to be eroded by inconsistent legislative and executive action and

72 The constitutional power of Congress to impose "exceptions and regulations" upon the appellate jurisdiction of the Supreme Court (U.S. CoNST. art. III, \$2), though frequently regarded as authorizing unlimited congressional control over that jurisdiction, probably does not sanction congressional impairment of the essential constitutional functions of the Court as the national tribunal of last resort: (1) to preserve nationwide uniformity of federal law by resolving inconsistent or conflicting interpretations by state and lower federal courts; (2) to maintain the supremacy of federal law when it conflicts with state law or is challenged by state authority. See Ratner, Congressional Pozerer Over the Appellate Jurisdiction of the Supreme Court, 109 U. PA. L. Rev. 157 (1960).

73 Professor Lon Fuller's comment on the judicial process of common law development is relevant to the judicial process of constitutional interpretation: "[I]t is not the function of courts to create new aims for society or to impose on society new basic directives" but rather to participate in "articulating the implications of [society's] shared purposes."

Quoted in P. Mishrin \& C. Morris, On Law In Courts 102-03 (1965).

${ }^{74}$ See Rostow, The Democratic Character of Judicial Review, 66 HaRv. L. Rev. $193,205-10$ (1952). 
ultimately abandoned by the Court if not sooner changed by constitutional amendment.) ${ }^{75}$

But a court that asserts authority to designate the community values that limit conduct-regulating policy is more likely to be viewed as a constitution-making than a constitution-interpreting institution, and its decisions are less likely to receive the deferential, tentative acceptance of a disagreeing or uncertain majority so important to effective testing of constitutional policy in the social arena. Consequently, the decisions of such a court may tend to reflect current majoritarian attitudes rather than long-range community goals.

\section{The Judicial Role: Limitations on ENFORCEMENT POLICY}

If due process limitations upon conduct-regulating authority ought not to be derived from nonconstitutional values, perhaps due process limitations on enforcement procedures may appropriately be drawn from such sources. ${ }^{76}$ Enforcement procedures are institutional mechanisms for resolving the public and private disputes that result from noncompliance with conduct-regulating policy, uncertainty as to the scope of that policy, and the difficulties of accurately perceiving, recalling, and describing events. Such procedures include apprehension of offenders, seizure of property, collection of evidence, and the conduct of hearings to ascertain relevant events and appropriate policy. Though sanctions and compensatory recovery are sometimes characterized as "remedial" because their deterrent effect reinforces socially approved behavior, they are encompassed by conduct-regulating policy, which is ordinarily conceived and articulated in terms of such remedial consequences.

Numerous limitations upon criminal enforcement procedures are included in the Bill of Rights; ${ }^{77}$ only three limitations upon noncriminal enforcement procedures are specified: a jury trial is required in suits at common law involving more than $\$ 20$, judges are denied authority to redetermine the facts after a jury trial, ${ }^{78}$ and unreasonable searches and seizures are forbidden. ${ }^{79}$ These Bill of Rights limitations

75 See A. Bickex, supra note 71, at 24-26, 37-42, 258 (1962).

76 See note 5 supra.

77 See notes 94-103, 117-18 infra and accompanying text.

78 U.S. Const. amend. VII.

79 U.S. CoNST. amend. IV. The language of this limitation reaches official conduct in both criminal and non-criminal proceedings. See Able v. United States, 362 U.S. 217 (1960) ; Frank v. Maryland, 359 U.S. 360 (1959) ; cf. Federal Trade Comm'n v. American Tobacco Co., 264 U.S. 298 (1924). See also State ex rel. White v. Simpson, 28 Wis. $2 \mathrm{~d} 590,137$ N.W.2d 391 (1965) ; Sackler v. Sackler, 15 N.Y.2d 40, 255 N.Y.S.2d 83, 203 N.E.2d 481 (1964). 
constitute the primary source of constitutional restraints on federal and state enforcement procedures.

The Supreme Court has not hesitated, however, to derive additional enforcement limitations from nonconstitutional sources. The "sense of justice" test was applied in Rochin 80 to a situation which could have been resolved by search and seizure and self-incrimination values, later recognized as applicable to the states. ${ }^{81}$ But the Court has used a "fair trial" test to invalidate on due process grounds enforcement-litigation procedures not proscribed by other constitutional provisions. In criminal cases it has interdicted the knowing use of false evidence by the prosecution, ${ }^{82}$ nondisclosure by the prosecution of important admissible evidence tending to exculpate the accused, ${ }^{83}$ "nonrational" presumptions tending to shift the risk of nonpersuasion to the accused, ${ }^{8 \pm}$ and trial by a judge with a financial or psychological stake in the outcome. ${ }^{85}$ In noncriminal proceedings it has required adequate notice, ${ }^{86}$ a reasonable opportunity to be heard, ${ }^{87}$ and a place of trial with litigant contacts sufficient to "satisfy traditional notions of fair play and substantial justice." 88

The due process clause has an independent enforcement-limiting function only if the constitutional plan supports judicial discretion to derive at least some limitations on enforcement procedures, though none on conduct-regulating policy, from nonconstitutional sources. The for-

80 Rochin v. California, 342 U.S. 165 (1952).

81 Malloy v. Hogan, 378 U.S. 1 (1964); Mapp v. Ohio, 367 U.S. 643 (1961); see Schmerber v. California, 384 U.S. 757 (1966).

82 Miller v. Pate, 386 U.S. 1 (1967) ; Napue v. Illinois, 360 U.S. 264 (1959); Pyle v. Kansas, 318 U.S. 213 (1942); Mooney v. Holohan, 294 U.S. 103 (1935); cf. Alcorta v. Texas, 355 U.S. 28 (1957).

83 Giles v. Maryland, 386 U.S. 66 (1967) ; Brady v. Maryland, 373 U.S. 83 (1963); cf. cases cited note 82 supra.

84 United States v. Romano, 382 U.S. 136 (1965) ; Tot v. United States, 319 U.S. 463 (1943) ; Morrison v. California, 291 U.S. 82 (1933); cf. Gainey v. United States, 380 U.S. 63 (1964).

85 In re Murchison, 349 U.S. 133 (1955) (judge adjudicated contempt charge based on defendant's conduct before same judge acting as a one-man grand jury); Tumey v. Ohio, 273 U.S. 510 (1927) (trial judge shared fine).

86 Schroeder v. City of New York, 371 U.S. 208 (1962); Mullane v. Central Hanover Bank \& Trust Co., 339 U.S. 306 (1950); Milliken v. Meyer, 311 U.S. 457 (1940); MacDonald v. Mabee, 243 U.S. 90 (1917); Grannis v. Ordean, 234 U.S. 385 (1914); Roller v. Holly, 176 U.S. 398 (1900).

87 Hansberry v. Iee, 311 U.S. 32, 40-41 (1940) ; Baldwin v. Iowa State Traveling Men's Ass'n, 283 U.S. 522 (1931); Twining v. New Jersey, 211 U.S. 78, 110-11 (1908). See also cases cited note 85 supra.

88 International Shoe Co. v. Washington, 326 U.S. 310, 316 (1945) ; accord, McGee v. International Life Ins. Co., 355 U.S. 220 (1957); cf. Hanson v. Denckla, 357 U.S. 235 (1958).

Early cases identified procedural due process as "those settled usages and modes of proceeding existing in the common and statute law of England, before the emigration of our ancestors and . . . acted on by them after the settlement of this country." Den ex dem. Murray v. Hoboken Land \& Improvement Co., 59 U.S. (18 How.) 272 (1855). See Ownbey v. Morgan, 256 U.S. 94 (1921); Kadish, supra note 28, at 321-26; cf. Tumey v. Ohio, 273 U.S. 510, 523-24 (1927). See also Hurtado v. California, 110 U.S. 516 (1884). 
mulation of conduct-regulating policy is perhaps the most difficult, sensitive, and encompassing of governmental functions. Ultimate formulation of such policy, consistent with constitutional limitations, is entrusted to the legislature. The conduct of litigation, ${ }^{89}$ on the other hand, is clearly the special province of the judiciary. While the legislature may participate in the fashioning of litigation policies, for the most part they are a product of judicial experience. Procedural legislation commonly ratifies that experience, or confirms the judicial rulemaking authority. Courts are particularly qualified not only to formulate policies for the efficient conduct of litigation but to perceive the essentials of a fair trial, ${ }^{90}$ and the community is likely to accord substantial deference to that judicial expertise.

The Constitution does not provide a comprehensive set of fair trial limitations. The Bill of Rights catalogue of criminal trial protections is extensive but incomplete. ${ }^{91}$ For noncriminal proceedings the specifications are rudimentary. ${ }^{92}$ In this context, the linguistic, historical, and functional connotations of due process of law ${ }^{93}$ suggest that the clause confers upon the courts authority to derive from the process of adjudication fair trial imperatives not otherwise indicated by the Constitution.

The function of adjudication is reconstruction of disputed events and determination of dispute-resolving policy for the purpose of implementing community values and minimizing social disruption. Fair trial values maintain the integrity and efficiency of that process. Primarily, they facilitate truth ascertainment, that is, accurate event reconstruction and intelligent policy determination. But they also promote expeditious and authoritative decision in order to conserve public and private resources, reduce public and private anxiety, and heal sources of social disaffection.

Bill of Rights restrictions on criminal litigation procedures implement for accused persons the following fair trial-truth ascertainment values: notice sufficient to prepare a defense, ${ }^{84}$ a hearing before impartial arbiters at a reasonably convenient place that is near the relevant evidence and not subject to the control of the government, ${ }^{95}$ an oppor-

89 Litigation occurs not only in conventional courts but before administrative agencies and perhaps before legislative committees as well.

90 See Shaughnessy v. United States ex rel. Mezei, 345 U.S. 206, 224 (1953)

(Jackson, J., dissenting); Kadish, supra note 28, at 321-26.

o1 See text at notes 82-85 supra.

92 See text at notes 78-79, 86-88 supra.

93 See note 4 supra and accompanying text; note 88 supra; text accompanying notes 89-90 sipra.

94 ". . . the accused shall ... be informed of the nature and cause of the accusation.." U.S. ConsT. amend. VI.

95 ". . . the accused shall enjoy the right to a . . trial, by an impartial jury of the State and district wherein the crime shall have been committed, which district shall have been previously ascertained by law . . " U..S. CoNȘT. amend. VI. 
tunity to discover and present relevant evidence and to test adverse evidence, ${ }^{96}$ exclusion of particularly unreliable evidence, ${ }^{97}$ effective presentation of the defense, ${ }^{98}$ control of the defense, ${ }^{99}$ psychological support and comfort, ${ }^{100}$ community surveillance and supervision of the criminal litigation process, ${ }^{101}$ and preservation of the ability to contend with superior government resources. ${ }^{102}$ Expeditious-decision values are implemented by inhibitions on delay and relitigation. ${ }^{103}$

The judicially developed proscriptions on knowing use of false evidence by the prosecution, nondisclosure by the prosecution of important exculpatory evidence, and trial by a predisposed judge ${ }^{104}$ also preserve for the accused the ability to discover and present evidence, to exclude particularly unreliable evidence, to contend with superior government resources, and to be heard by impartial arbiters. But the enumerated requirements that reflect these values are too specific to reach the additional protections. ${ }^{105}$ The implications of those values have been extended to the new protections by judicial appraisal of the adjudication process, much as common law doctrine is extended by analogy through judicial appraisal of community needs. And the unenumerated inhibition on shifting the burden of persuasion to the accused ${ }^{106}$ reflects not only the constitutional recognition of superior government resources but also a judicially derived, independent truth ascertainment value that minimizes for the accused the risk of adjudication mistakes. ${ }^{107}$

The jury trial and limited review requirements for noncriminal litigation insure community supervision of the adjudication process. ${ }^{108}$

96 ". . . the accused shall enjoy the right to a . . . public trial, . . to be confronted with the witnesses against him; to have compulsory process for obtaining witnesses in his favor; and to have the Assistance of Counsel for his defence." U.S. CoNST. amend. VI' (emphasis added).

97 U.S. CoNST. amend. VI: confrontation of witnesses (hearsay protection); U.S. CoNst. amend. V: self-incrimination privilege (protection against coerced confessions).

98 U.S. CoNST. amend. VI: assistance of counsel.

99 U.S. CoNsT. amend. V: self-incrimination privilege (protection against prosecutor comment on failure of accused to testify, see note 281 infra); U.S. CoNST. amend. VI: compulsory process for obtaining witnesses.

100 U.S. CoNST. amend. VI: assistance of counsel.

101 U.S. CoNST. amend. VI: public trial (surveillance), by jury (supervision); U.S. CoNST. amend. V: grand jury indictment (supervision).

102 U.S. CoNST. amend. V: self-incrimination privilege, double jeopardy; U.S. Const. amend. VI: assistance of counsel.

103 U.S. Consr. amend. VI : speedy trial ; U.S. CoNsT. amend. V : double jeopardy.

104 See notes $82-83,85$ supra.

105 See notes 95-97, 102 supra.

${ }_{106}$ See note 84 supra.

107 See Morrison v. California, 291 U.S. 82 (1933). Perhaps this burden of proof value is reflected by the self-incrimination inhibition against enforced examination of the accused and against prosecutorial comment on failure of an accused to testify.

108 See notes 78 supra, 286 infra and accompanying text. 
Because the specified limitations are so few, most due process requirements for such litigation reflect fair trial values judicially derived from the adjudication process and perhaps, by analogy, from constitutionally specified criminal trial protections. Modern due process requirements for judicial jurisdiction that reject the power-territory concept of Pennoyer $v$. Neff ${ }^{109}$ are judicially derived from truth ascertainment and expeditious decision values concerned with a place of litigation convenient to the parties ${ }^{110}$ or economically accessible to an inconvenienced party through use of the pricing mechanism to distribute litigation costs ; ${ }^{111}$ a place where there is optimal access to the evidence; ${ }^{112}$ where disputed or attachable property can be immobilized and supervised; ${ }^{113}$

10995 U.S. 714 (1878). See J. Story, Commentaries on the Conflict of Laws (1834). The Pennoyer concept rested on the premise that persons and property located on forum territory can be seized there at the outset of private litigation. Service of process on a defendant within forum boundaries was viewed as the equivalent of seizure, and international recognition of judgments thus obtained was considered necessary to support the substitution of service for seizure. MacDonald v. Mabee, 243 U.S. 90, 91 (1917); Michigan Trust Co. v. Ferry, 228 U.S. 346, 353, 356 (1913); see International Shoe Co. v. Washington, 326 U.S. 310 (1945). This proposition was distended into the generalization that only defendants served on forum territory or otherwise subject to forum control could be personally subjected to forum judicial authority. The generalization disregarded not only reciprocity values suggesting collaborative development of mutually advantageous jurisdictional doctrine, but also fair trial values suggesting that jurisdiction based solely on transient presence unfairly disadvantages the defendant and that denial of jurisdiction over absent defendants sometimes unfairly disadvantages the plaintiff. See text at notes 110-16 infra. The impact of such values promptly distorted the concept. See Pennoyer v. Neff, 95 U.S. 714 (1878); Sugg v. Thorton, 132 U.S. 524 (1889); Michigan Trust Co. v. Ferry, supra; MacDonald v. Mabee, supra; Hess v. Pawloski, 274 U.S. 352 (1927) ; Blackmer v. United States, 284 U.S. 421 (1932) ; Doherty \& Co. v. Goodman, 294 U.S. 623 (1935) ; Hansberry v. Lee, 311 U.S. 32 (1940); Milliken v. Meyers, 311 U.S. 457 (1940); International Shoe Co. v. Washington, supra. Within the United States the Pennoyer "power" premise is meaningless because no state has the physical power to seize persons or property on its territory when such action is forbidden by the physically dominant national authority. Power, thus, is not a relevant standard for constitutional allocation of judicial authority among the states. It is a conclusion, not a reason, and reduces the Pemoyer concept to a tautology.

$110 \mathrm{McGee}$ v. International Life Ins. Co., 355 U.S. 220 (1957); International Shoe Co. v. Washington, 326 U.S. 310 (1945); cf. Hanson v. Denckla, 357 U.S. 235 (1958).

111 See McGee v. International Life Ins. Co., 355 U.S. 220 (1957) ; Liquid Carriers Corp. v. American Marine Corp., 375 F.2d 951 (2d Cir. 1967); Deveny v. Rheem Mfg. Co., 319 F.2d 124 (2d Cir. 1963); WSAZ Inc. v. Lyons, 254 F.2d 242 (6th Cir. 1958); Schutt v. Commercial Travellers Mut. Accid. Ass'n, 229 F.2d 158 (2d Cir. 1956); Continental Oil Co. v. Atwood \& Morril Co., 265 F. Supp. 692 (D.Mont. 1967); Gray v. American Radiator \& Standard Sanitary Corp., 221 Ill.2d 432, 176 N.E.2d 761 (1961); Ehlers v. United States Heating \& Cooling Co., 267 Minn. 56, 124 N.W.2d 824 (1963); Longines-Witnauer Watch Co. v. Barnes \& Reinecke, Inc., 15 N.Y.2d 443, 261 N.Y.S.2d 8, 209 N.E.2d 68 (1965); $c f$. Hellriegel v. Sears, Roebuck \& Co., 157 F. Supp. 7, 8 (N.D. Ill. 1957); O'Brien v. Comstock Food, Inc., 123 Vt. 461, 194 A.2d 568 (1963).

112 See McGee v. International Life Ins. Co., 355 U.S. 220, 223 (1957) ; Fisher Governor Co. v. Superior Court, 53 Cal.2d 222, 1 Cal. Rptr. 1, 347 P.2d 1 (1959).

113 See North Carolina Land \& Lumber Co. v. Boyer, 191 F. 552, 557 (6th Cir. 1911) ; Martin v. Better Taste Popcorn Co., $89 \mathrm{~F}$. Supp. 754,757 (S.D. Iowa 1950); Beach v. Youngblood, 215 Iowa 979, 247 N.W. 545 (1933) ; Educational Studios, Inc. v. James Cruze Productions, Inc., 112 N.J. Eq. 352, 164 A. 24 (1933). 
where multiplicity and relitigation will be minimized, ${ }^{114}$ set-offs facilitated, ${ }^{115}$ child abduction discouraged, ${ }^{116}$ and harassment inhibited.

Constitutionally specified enforcement limitations also reflect values concerned not with fair trials but with privacy intrusion, harassment and brutality by overzealous or overbearing officials, ${ }^{117}$ and with maintaining an informed community. ${ }^{118}$ Fair trial values are not reflected by the unreasonable search and seizure protection. Exclusion of evidence thus obtained subordinates effective truth ascertainment to the privacy, antibrutality, and antiharassment values. ${ }^{118}$ The guarantees of notice, confrontation and compulsory attendance of witnesses, and assistance of counsel primarily reflect fair trial values. The other enforcement limitations reflect both kinds of values. ${ }^{120}$

Enforcement limitations based upon other than fair trial values are outstide the area of special judicial expertise. Their derivation from nonconstitutional sources thus lacks constitutional justification. ${ }^{121}$ This distinction is confirmed by the practice of the Court. Although lip service continues to the Rochin "sense of justice" standard, ${ }^{122}$ no enforcement limitations have been judicially imposed that do not in fact reflect either constitutionally indicated or fair trial values.

\section{Due Process and the Ninth Amendment: The Social Purpose Limitation}

The function of the due process clause is circumscribed if it provides no independent standard for limiting the conduct-regulating authority of government. The history of the clause, however, and the

114 See Mullane v. Central Hanover Bank and Trust Co., 339 U.S. 306 (1950) ; Adam v. Saenger, 303 U.S. 59 (1938) ; Baldwin v. Iowa State Travelling Men's Ass'n, 283 U.S. 522, 525 (1931); Fisher Governor Co. v. Superior Court, 53 Cal.2d 222, 1 Cal. Rptr. 1, 347 P.2d 1 (1959); Atkinson v. Superior Court, 49 Cal.2d 338, 316 P.2d 960 (1957). See also cases cited note 113 supra.

115 Adam v. Saenger, 303 U.S. 59 (1938); see Griffin v. Griffin, 327 U.S. 220 (1946) ; Worthley v. Worthley, 44 Cal.2d 465, 283 P.2d 19 (1955).

110 See Ratner, Child Custody in a Federal System, 62 MrcH. L. Rev. 795 (1964); Ratner, Legislative Resolution of the Interstate Child Custody Problem: A Reply to Professor Currie and a Proposed Uniform Act, 38 S. CAL L. Rev. 183 (1964); cf. May v. Anderson, 345 U.S. 528, 548 (1953) (Jackson, J., dissenting).

117 U.S. CoNST, amend. IV: unreasonable searches and seizures (privacy, harassment, brutality); U.S. CoNST, amend. V: self-incrimination privilege (privacy and harassment: questioning without probable cause for arrest and constant questioning after arrest; brutality : coerced confessions); U.S. CoNST. amend. V: grand jury indictment (harassment), speedy trial (harassment), double jeopardy (harassment); U.S. CoNST. amend. VIII: excessive bail (privacy, harassment, brutality). text.

118 U.S. Const. amend. VI: public trial; cf. notes 96, 101 supra and accompanying

119 See text accompanying note 312 infra.

120 See notes 96-99, 101-03, 117-18 supra and accompanying text.

121 See text accompanying notes 67-75 supra.

122 See Schmerber v. California, 384 U.S. 757, 760 (1966). 
pivotal position it has acquired as a constitutional regulator of official power evidence tenacious judicial awareness of an underlying due process value that protects the individual from overreaching governmental regulation. And the admonition of the ninth amendment, that rights other than those enumerated in the Constitution are retained by the people, implies an independent, though inexplicit, limitation on government, an implication reinforced by Madison's design to rebut any inference that "those rights . . . not singled out [for enumeration in the Constitution] were . . assigned into the hands of the General Government and were consequently insecure." 123

Justice Black's assertion that the ninth amendment was adopted "to limit the Federal Government to the powers granted expressly or by necessary implication" ${ }^{124}$ makes that amendment a repetition of the tenth. The tenth amendment reserves to the states or the people the "powers" not delegated to the federal government. The ninth amendment is a reservation of "rights" by the people, not an allocation of powers among governments. Like the preceding amendments, it is concerned with limiting the exercise of the delegated federal powers, not with their delegation. ${ }^{125}$

Nor does the language of the ninth amendment or the context of its enactment indicate that it was designed as simply a canon of liberal constitutional construction, a kind of necessary and proper clause saying, in effect: The provisions of the foregoing amendments shall be liberally construed to extend to those rights implied therein though not expressly set forth. Madison would not likely have used the oblique language of the amendment and of his congressional explanation to express that conventional legal idea. ${ }^{126}$ The amendment does not incorpo-

\section{Annals of Congress 439 (1789).}

124 Griswold v. Connecticut, 381 U.S. 479, 520 (Black, J., dissenting).

125 See generally Griswold v. Connecticut, 381 U.S. 479, $488-93$ (1965) (Goldberg, J., concurring); B. PatTerson, The ForgotTen Ninth AMAENDMENT (1955); Kelsey, The Ninth Amendment of the Federal Constitution, 11 IND. L. REv. 309 (1936); Redlich, Are There "Certain Rights . . Retained by the People" 9,37 N.Y.U.' L. Rev. 787, 802-06 (1962). See also United Public Workers v. Mitchell, 330 U.S. 75, 94-95 (1947); Tennessee Electric Power Co. v. TVA, 306 U.S. 118, 143-44 (1939); Ashwander v. TVA, 297 U.S. 288, 330-31 (1936). read:

126 The enacted amendment is less wordy than Madison's original draft, which

The exceptions here or elsewhere in the Constitution, made in favor of particular rights, shall not be so construed as to diminish the just importance of other rights retained by the people, or as to enlarge the powers delegated by the Constitution; but [shall be construed] either as actual limitations of such powers, or as inserted merely for greater caution.

1 AnNals of Congress 435 (1789). See also Madison's general discussion of the ambiguity of language in THE FEDERALIST No. 37 at 229 (C. Rossiter ed. 1961):

The use of words is to express ideas. Perspicuity, therefore, requires not only that the ideas should be distinctly formed, but that they should be 
rate; it differentiates. Protection is extended not to rights implicitly encompassed by those previously enumerated but to "others retained by the people."

The amendment may appear to authorize limitations on federal authority judicially derived from an inchoate reservoir of natural rights, a reservoir that would also provide a likely source of fourteenth amendment due process limitations on the states. ${ }^{127}$ But such a construction confers upon the judiciary a carte blanche discretion, to designate limitations on the other branches of government, that is at variance with the constitutional plan of written limitations interpreted and applied by the judiciary. ${ }^{128}$ And the constitutional plan of judicially enforceable restraints negates a view of the ninth amendment as no more than a reassuring acknowledgment of residual, but judicially unenforceable, rights. Rather, the assertion of other rights "retained by the people" suggests recognition of a limitation on federal authority generally understood but not explicitly stated, perhaps because not clearly articulated in the minds of drafters, Congress, and voters.

.The due process and residual rights concepts connote a basic limitation upon governmental authority, derived from the function of government and the official-citizen relationship. They imply that government may restrict human activity only for a socially useful purpose, that every government regulation should implement some community value.

This limitation sustains individual autonomy in choice of goals. It preserves for each person optimal freedom to determine his needs and the ways to fulfill them. It inhibits oppressive official conduct and promotes community involvement in the formulation of policy. The electoral process, being slow, inefficient for oppressed minorities, and inappropriate for retroactive redress, is not alone an adequate mechanism for preserving these values.

The social compact philosophy reflects this norm. The notion of such a compact conceptualizes government as a product of communal living, with the function of restraining individuals and allocating resources for the common good. This concept, amplified by the Utili-

expressed by words distinctly and exclusively appropriated to them. But no language is so copious as to supply words and phrases for every complex idea, or so correct as not to include many equivocally denoting different ideas. Hence it must happen, that however accurately objects may be discriminated in themselves, and however accurately the discrimination may be conceived, the definition of them may be rendered inaccurate, by the inaccuracy of the terms in which it is delivered.

and Chief Justice Marshall's extended discussion of express and implied powers in McCulloch v. Maryland, 17 U.S. (4 Wheat.) 316 (1819).

$127 \mathrm{See}$ authorities cited note 125 sipra.

128 See text accompanying notes $11-13,67-75$ sipra. 
tarians, ${ }^{129}$ is reflected in the Declaration of Independence ${ }^{130}$ and the preamble to the Constitution. ${ }^{131}$

In this light the language of the due process clause acquires more definite coloration. The connotations of "life, liberty, or property" as the totality of human activity and of "law" as policy formulated and enforced by government to promote the general welfare convey the idea that government may interfere with human activity only for a socially useful purpose. And in this context the rights reserved in the ninth amendment are the rights of individuals to act without inhibition by governmental restrictions that accomplish no social purpose.

\section{Judicial Recognition of the Social Purpose Limitation}

The social purpose limitation was implicit in the traditional doctrine that state authority to regulate for the general welfare, called "police power," could justify intrusion on activity otherwise accorded due process protection. ${ }^{132}$ But police power, for the most part, was a conclusion, not a standard of decision. The presence of a social benefit did not insulate the regulation from successful due process attack. Rather, the benefit became a counterpoise balanced against the detriment resulting from impairment of natural law values. If the benefit appeared to outweigh the detriment, the regulation was upheld as an exercise of the police power. If the detriment seemed heavier, the regulation was invalidated as beyond the police power. Police power thus became a label that described the outcome of the balance, a balance likely to be resolved by judicial attitudes concerning the wisdom of the regulation when substantial and essentially nonquantifiable values were on both sides of the scale. ${ }^{133}$

120 See generally D. Baumgardx, Bentham aNd THE Ethics of Today 23-79 (1952); J. Bentham, A Fragment on Government (F. Montague ed. 1891); J. S. Mili, Considerations on Representative Governament (3d ed. 1865); J. S. Mili, Utilitarianisas (2d ed. 1864); J. Planientz, The English Utilitarians (1949)

130 ". . . That whenever any form of government becomes destructive of these ends [Life, Liberty, and the Pursuit of Happiness], it is the Right of the People to alter or to abolish it, and to institute new Government, laying its foundation on such principles and organizing its powers in such form, as to them shall seem most likely to effect their Safety and Happiness . ..."

131 "We the People of the United States, in Order to form a more perfect Union, establish Justice, insure domestic Tranquility, provide for the common defence, promote the general Welfare, and secure the Blessings of Liberty to ourselves and our Posterity, do ordain and establish this Constitution for the United States of America."

132 See cases cited notes 16, 18 supra, and 136 infra; Brown, Due Process of Lav, Police Power, and the Supreme Court, 40 HARv. L. REv. 943, 952-53 (1927) ; Kales, "Due Process", The Inarticulate Major Premise and the Adamson Act, 26 YALE L.J. 519,521 (1917).

133 See cases cited notes 16, 18 supra, and 136 infra; Brown, supra note 132, at 956-67; Corwin, Social Planning Under the Constitution, 26 AM. PoL. SCI. REV. 1, 17 (1932); Cushman, The Social and Economic Interpretations of the Constitution, 20 Mrcr. L. REv. 737, 758 (1922) ; Kales, supra note 132, at 520; cf. Lerner, The Strpreme Court and American Capitalism, 42 YAIE L.J. 668 (1933). 
The general right to make a contract in relation to his business is part of the liberty of the individual protected by the 14th Amendment of the Federal Constitution, said the Supreme Court in Lochner v. New York. ${ }^{134}$

[T] he question necessarily arises: Is this a fair, reasonable, and appropriate exercise of the police power of the State, or is it an unreasonable, unnecessary, and arbitrary interference with the right of the individual to his personal liberty . . . ?

$\therefore$. There is no reasonable ground for interfering with the liberty of person or the right of free contract, by determining the hours of labor, in the occupation of a baker. ${ }^{135}$

The Court later repudiated the Lochner result by discerning that the benefits of maximum-hour regulation were, after all, heavier than the resulting impairment of the due process - free enterprise value, ${ }^{136}$ a value that nevertheless remained for some time corpulent enough to outweigh the social benefits of wage, price, yellow-dog contract, and business licensing regulations. ${ }^{137}$ When the constitutional shelter for that value was finally removed, ${ }^{138}$ the balancing process was stultified. The social benefits were left on one side of the scale, but with no impairment of constitutional values on the other. Consequently, the Court was compelled to focus more directly upon the nature of the due process function. If contracting is entitled to no special constitutional protection, it is nevertheless an important human activity which should not be subject to unlimited governmental restraint; any such restraint should be for a socially useful purpose. Thus Chief Justice Hughes wrote for the majority that sustained minimum wage laws for women in $W e s t$ Coast Hotel Co. v. Parrish: ${ }^{139}$

The Constitution does not speak of freedom of contract. It speaks of liberty .... [T] in a social organization which requires the protection of law against the evils which menace the . . . welfare of the people. Liberty under the Constitution is thus necessarily subject to the restraints of due process, and regulation which is reasonable in relation to its subject and is adopted in the interest of the community is due process. ${ }^{140}$

134198 U.S. 45,53 (1905).

$135 \mathrm{Id}$. at $56-57$. (1917).

136 Muller v. Oregon, 208 U.S. 412 (1908) ; Bunting v. Oregon, 243 U.S. 426

137 See cases cited note 16 supra; W. Lockhart, Y. Kamisar \& J. Choper, ConStTtutional Law: Cases, Comments, Questrons 494-95 (2nd ed. 1967).

$138 \mathrm{See}$ cases and authorities cited note 19 supra.

139300 U.S. 379 (1937).

$140 \mathrm{Id}$. at 391 . 
But upon upholding state regulation of employment agency rates in Olsen $v$. Nebraska ${ }^{141}$ the Court seemed to cast aside all due process restraint on economic regulation, including the social purpose limitation, by declaring:

Respondents urge that ... there are no conditions which the legislature might reasonably believe would redound to the public injury unless corrected by such legislation.

We are not concerned, however, with the wisdom, need, or appropriateness of the legislation ... . There is no necessity for the state to demonstrate before us that evils persist ... ${ }^{142}$

By this exuberant language, however, the Court may have intended no more than to indicate that the state does not have the initial burden of justifying its regulation, and that a legislative choice between debatable policies, each with an identifiable social purpose, should not be judicially controverted. ${ }^{143}$ The social purpose limitation was perhaps suggested a few years earlier by the statement in United States $v$. Carolene Products Co. ${ }^{144}$ that legislation must rest "upon some rational basis within the knowledge and experience of the legislators," ${ }^{145}$ and acknowledged a few years later by the declaration in Daniels v. Family Security Life Insurance Co.:

We cannot say that South Carolina is not entitled to call the funeral insurance business an evil. Nor can we say that the statute has no relation to the elimination of those evils. There our inquiry must stop. ${ }^{148}$

More recently, in Goldblatt $v$. Hempstead, ${ }^{147}$ the Court, upon upholding an ordinance that prohibited excavations below the water table, gave verbal support to the social purpose limitation by stating:

The ordinance . . . was passed as a safety measure . . .

To evaluate its reasonableness we therefore need to know such things as the nature of the menace against which it will protect [and] the availability and effectiveness of other less drastic protective steps ....148

141313 U.S. 236 (1941).

142 Id. at 246 (Douglas, J.).

143 See Day-Brite Lighting, Inc. v. Missouri, 342 U.S. 421, 425 (1952).

144304 U.S. 144 (1938).

$145 I d$. at 152 .

148336 U.S. 220 at 224 (1949). See also Williamson v. Lee Optical Co., 348 U.S. 483, 487 (1955) ; Day-Brite Lighting, Inc. v. Missouri, 342 U.S. 421, 425 (1952); Lincoln Federal Labor Union v. Northwestern Iron \& Metal Co., 335 U.S. 525, 536-37 (1949).

147369 U.S. 590,595 (1962).

$148 I d$. at 595. 
But the Court was reluctant to apply the limitation. Although unable to think of a reason why the threat to public safety would be increased by further excavation of gravel from a private lake already 25 feet deep, ${ }^{149}$ it nevertheless denied relief to the landowner partly because he had failed to come forward with evidence showing that further excavation would not increase the danger. ${ }^{150}$

The social purpose limitation is authoritatively recognized when applied to invalidate a regulation. No economic legislation has been judicially invalidated on due process grounds since $1937 .^{151}$ Many cases upholding challenged regulations contain language that appears to acknowledge the limitation, ${ }^{152}$. but due process invalidation of noneconomic controls has almost invariably rested on impairment of more specific values derived from constitutional or nonconstitutional sources, with failure to imolement a social purpose sometimes providing auxiliary support. ${ }^{1 .}$

In Griswold, for example, four justices pointed out that the ban on use of contraceptives by married persons to prevent conception but not disease failed to implement the state's asserted goal of discouraging marital infidelity. ${ }^{154}$ Yet these four, and the three others who voted to invalidate, struggled to find impairment of a fundamental due processmarital privacy value, dividing over whether that value could be derived from the penumbra of specified constitutional protections, from unspe-

$149 \mathrm{Id}$. See text accompanying note $265 \mathrm{infra}$. The purpose of the ordinance apparently was to reduce the drowning hazard by inhibiting the creation of deep ponds and lakes. Further deepening of a lake already 25 feet deep would not appear to increase that hazard.

150 See note 288 infra, and text accompanying note 265 infra. The landowner had complied with enclosure, berm, and slope requirements. The ordinance also required that such excavations be refilled, but the town apparently made no attempt to impose that obligation on the landowner, perhaps because strong retroactivity values would strengthen his claim to eminent domain compensation. The Supreme Court denied the compensation claim because the landowner had presented no evidence that the land's value was reduced by prohibition of further mining.

151 See W. Lockhart, X. KaMrsar \& J. Choper, supra note 137, at 516; McCloskey, Economic Due Process and the Supreme Court: An Exhumation and Reburial, 1962 Sup. CT. REv. 34, 38.

152 See cases cited notes $18,136,139,144-47$ supra.

153 See Bolling v. Sharpe, 347 U.S. 497 (1954); cases cited notes 15, 25-29, 46 sipra. Failure to implement a social purpose sometimes provided auxiliary support for earlier invalidation of economic regulations. See Lochner v. New York, 198 U.S. 45 (1905) ; cases cited note 16 supra; cases collected in Brown, supra note 132, at $944 \mathrm{nn}$. 8-10 (1927); cases collected in W. LockHART, Y. KAMISAR \& J. CHOPER, supra note 137 , at 494-95; Bolling v. Sharpe, supra. See also Jay Burns Baking Co. v. Bryan, 264 U.S. 504 (1924), invalidating a bread weight regulation in part because "the provision, that the average weights shall not exceed the maximums fixed, is not necessary for the protection of purchasers against imposition and fraud by short weights and is not calculated to effectuate that purpose. . ." Id. at 517.

154381 U.S. at 498 (Goldberg, Brennan, JJ. \& Warren, C.J., concurring) ; 381 U.S. at 505-06 (White, J., concurring). The state did not, and could not in good faith, assert a policy of population expansion; nor did it suggest a policy reflecting religious disapproval of contraception. See text accompanying note 310 infra. 
cified residual ninth amendment rights, or from other nonconstitutional sources.

The status of social purpose as a due process standard is thus uncertain. The Supreme Court has been reluctant to apply it to economic regulation; as a test of other than economic regulation it remains subordinate to the process of balancing rights derived from constitutional and nonconstitutional sources against the social benefits of challenged regulations.

\section{The Nature of Socral Purpose}

"Socially useful purpose" is a broad concept concerned with the utility of ends and the efficiency of means. ${ }^{155}$ If courts accept as socially useful only the goals they approve, the standard is simply another designation for judicially derived natural rights. ${ }^{158}$ But application of the social purpose limitation differs significantly from the process of perceiving natural rights and balancing their impairment against social benefits.

Regulatory purpose is ascertained by identifying the problems that evoked the regulation and by discerning its function in the network of institutional controls. When applied to legislative regulation, the process is called statutory interpretation. A similar process discloses the purpose of executive or administrative regulations and of common law rules interpreted in the context of judicial applications rather than legislative history and administrative practice. ${ }^{157}$

A socially useful regulatory purpose is concerned with the fulfillment of basic human needs, that is, with providing those personal requisites regarded by almost the entire community as important to meaningful existence. Identification of these needs on a high level of generality does not involve a controversial value judgment. A broad consensus recognizes such basic needs as food and drink, clean air, protection from the elements, sexual enjoyment, good health, avoidance of physical injury, relief from pain, release from anxiety, discharge of

155 There is, of course, no sharp distinction between ends and means. In the inevitable hierarchy of values that underlies a system of order, ends are means to more important ends. Social problems are resolved not by the choice first of ends and then of means, but by the fashioning of an ends-means pattern. Tradition and experience suggest the often-competing, tentative ends that serve as hypotheses for the testing of means to resolve problems. Deficiencies in available means compel modification of the tentative ends, and further testing until means are found that substantially implement the modified ends. In this context, differentiation of regulatory goals and methods is useful in applying the social purpose limitation.

156 See note 7 supra.

157 Application of the social purpose limitation does not compel a judicial choice between tenable, alternative regulatory purposes. If either is consistent with the limitation, the regulation should stand. State court identification of state regulatory purpose is ordinarily authoritative when the case is reviewed by the United States Supreme Court. Identification of state regulatory purpose by lower federal courts may be necessary in cases originating there when the identification is not provided by state decisions. 
aggression, comfort, entertainment, affection, companionship, communication, knowledge, esthetic expression, privacy, dignity, and activity.

Fulfilment of every need is not essential to individual survival, though fulfillment of each has obvious survival value. Environmental limitations produce competing needs as well as competition between individuals to fulfill them. But social living does not compel diminution in the total need fulfillment of each individual to allow fulfillment by others. Men live together because the needs of each are more adequately fulfilled by communal living than by isolated existence. Effective social arrangements enhance that fulfillment. ${ }^{158}$

The values of a community are designs for optimal need fulfillment. They accommodate or assign priorities to competing needs. They are products of a social evolution that involves human adjustment to environmental changes, elaboration of habits and conditioned responses, transmittal of traditions, and private and public discussion and ordering.

Because the Darwinian process apparently winnows social as well as physiological variations, the viability of a value probably depends upon its relevance to the long-range survival of community members. Such survival is generally recognized as a community imperative despite the inclination of some and the ambivalence of many toward selfdestruction..$^{159}$ A community may willingly sacrifice a good many individuals in war and other hazardous activity to preserve a particular social structure for the others. ${ }^{100}$ But that structure is usually preferred because in the community's view it more effectively fulfills needs essential or important to long-range survival.

The values of a community are thus intermediate goals that emerge from social competition and dispute. They are not ends divorced from means but rather an amalgam of ends and means molded by the pressure of available resources, reflected by linguistic usage, and discernible in the pattern of solutions to specific problems. Though wide acceptance results from their verbalization on a level of ambiguous generality, tension between them is inevitable in areas of particular application. ${ }^{161}$

Legislative enactment and judicial dispute-resolution are aspects of the process of value evolution. The two institutions are engaged in discerning and articulating the values relevant to the solution of social problems, that is, in making policy. This policy-making function in-

158 See H. Hart \& A. Sachs, The Legal Process 111 (Tent. ed. 1958).

159 Rarely, a community may choose extinction over oppressive survival.

160 Most are willing to run the risk because the possibility of extinction for a given individual is relatively small. Some willingly die to safeguard preferred values for the survivors.

161 The sharply divergent policy initiated by revolution reflects not newly constructed values but emergent values disregarded by the previous government. 
volves an interstitial shaping of values within the contours carved by long-term social forces, a shaping implicit in verbalization. Developing values emerge from the accommodations and choices compelled by competing, established values. The result is formulation of principles that articulate the values as formulas for resolving broadly related problems, and rules that increase predictability and administrative efficiency by specifying solutions to more particularized problems. The legislative formulations are usually in terms sufficiently general to reach an indeterminate number of variable, future situations, some anticipated, some not, at the time of enactment; the judicial formulations are often in the narrower terms appropriate to the resolution of specific disputes.

When legislative policy is unformulated or uncertain, judicial perception of social needs and social structure discloses dispute-resolving values, a perception that is necessarily a product of the experience and attitudes of each judge. Judicially enforced limitations on government are derived from values, concerning the relationship of government and the individual, so important to the community that they are accorded recognition in broadly phrased constitutional provisions. These values are more significantly shaped by judicial delineation than values underlying specific statutory directives and less significantly shaped by such delineation than unwritten dispute-resolving values. The constitutional values are judicially identified, illuminated, and accommodated within the framework provided by the textual, historical, and contemporary functional context of the constitutional language. ${ }^{162}$

But judicial identification of nonconstitutional community values is required to implement the due process-social purpose limitation, which directs the court to measure regulatory purpose against such values. The process, nevertheless, need not result in the "constitutionalization" of judicially favored values. In executing this constitutional function the court considers whether the purpose of the regulation is to advance recognizable community values, values perhaps controversial but accepted by a substantial portion of the community and not inconsistent with other constitutional provisions. If the purpose reflects such values, the court considers whether they will be significantly implemented by the regulatory method. Judicial concern is focused not on "fundamental rights" but on legislative goals and methods of achieving them.

The scope of the value judgment is limited. The court evaluates not the comparative utility of competing policies, but the minimal utility of the policy adopted. Despite the lumping together of natural justice and social purpose by Justice Black in Griswold, ${ }^{168}$ the evaluation does 
not involve a balancing of nonquantifiable fundamental rights and community benefits, with the scales likely to be tipped in favor of the judicially preferred policy. A socially useful purpose is identified not by totting up opposing weights, nor by perceiving that one side of the scale has dropped below the point of equilibrium, but by discerning significant community values on the side of the regulation. ${ }^{164}$

\section{Appraisal of Regulatory Goals and Methods}

In the identification of social purpose a broad deference is necessarily accorded the legislative choice of goals ${ }^{165}$ because the legislature mirrors community attitudes and the accommodations that emerge from the enacting process generally disclose community values. Such values are missing only from regulations that contradict more specific constitutional directives and from absurd or corrupt regulations that suggest a malfunctioning of the regulatory process, such as a requirement that every automobile carry a bumper sticker bearing the legend "Bumper Sticker" ${ }^{166}$ or that every resident wear a pin in the shape of a donkey, adopted at the urging of a legislator with a large supply of such pins on hand. And evidence of unusual social conditions might relate even such outlandish regulations to a community value.

More significant is the judicial appraisal of regulatory method to determine whether it implements the regulatory goal. ${ }^{167}$ The legislative choice of method need not be accorded the deference due the legislative choice of goal, because conduct-regulating policy is not nullified by judicial rejection of method. The Court is engaged not in negating legislative purpose but in assisting the legislature to achieve its policy within the constitutional framework. A legislature "advised" by the judiciary that the selected method of regulation is ineffective remains free to adopt a more effective method.

A method that does not significantly implement the social purpose of the regulation, while unusual, is not so rare as a regulation that lacks such a purpose. In Griswold, the four justices who questioned the utility of the anticontraceptive regulation conceded that discourag-

${ }^{164}$ Cf. Jaffe, Was Brandeis an Activist? The Search for Intermediate Premises, 80 Harv. $\dot{L}$. REv. 986, 998 (1967).

165 The purpose of an administrative regulation must reflect the purpose of the authorizing statute.

168 See MAD no. 112, July, 1967, inside cover.

167 The social benefit that a regulation is designed to achieve can usually be differentiated from the techniques provided to achieve it. The purpose of a 65 mile per hour speed limit is to inhibit accidents. Fast driving is not harmful, but accidents are, and experience indicates that fast driving significantly increases their number. The basic needs of pain and injury avoidance, on the one hand, and comfort, entertainment, and communication, on the other, are accommodated by the value that very fast driving should be discouraged to inhibit accidents. The method chosen by the legislature to achieve that value is a specific speed limit of 65 miles per hour, a method that obviously implements the statutory goal. 
ing marital infidelity was an appropriate goal but pointed out that the method of regulation (prohibiting use to avoid conception but not dis ease) did not significantly implement that goal. ${ }^{168}$

An unenforceable regulation does not implement its purpose. Sustained absence of significant enforcement in the presence of widespread violation indicates a lack of community inclination or capacity to implement the regulatory purpose by the regulatory method or, perhaps, by any method. Such unenforceability can be judicially ascertained. Poe v. Ullman ${ }^{169}$ and Griswold disclose that for eighty years the Connecticut anticontraceptive regulation had been enforced only against birth control clinics ${ }^{170}$ and a few "proprietors" who had been "picked up" on the streets. ${ }^{171}$ Marital infidelity is not discouraged by such selective enforcement. Justice White, concurring in Griswold, pointed to the obvious deterrent impotence of a ban on contraceptive use in the presence of "total nonenforcement . . . and apparent nonenforceability." 172

\section{Rationality as a Test of Social Purpose}

The Supreme Court has indicated that almost total deference is due a "rational" legislative choice of the goals and methods of economic regulation. ${ }^{173}$ Rationality is probably an alternative verbalization of

168 See note 154 supra. As Justice White stated:

... the statute is said to serve the State's policy against . . . illicit sexual relationships

Without taking issue with the premise that the fear of conception operates as a deterrent to such relationships in addition to the criminal proscriptions . . . I wholly fail to see how the ban on the use of contraceptives by married couples in any way reinforces the State's ban on illicit sexual relationships . . . [T] he sale of contraceptives to prevent disease is plainly legal under Connecticut law.

381 U.S. at 505 (White, J., concurring).

In these circumstances one is rather hard pressed to explain how the ban on use by married persons in any way prevents use of such devices by persons engaging in illicit sexual relations . . . Perhaps the theory is that the flat ban on use prevents married people from possessing contraceptives and without the ready availability of such devices for use in the marital relationship, there will be no or less temptation to use them in extramarital ones. This reasoning rests on the premise that married people will comply with the ban in regard to their marital relationship. . but will not comply with criminal statutes prohibiting extra marital affairs and the anti-use statute in respect to illicit sexual relationships. . .

Id. at 506; see also Southern Pacific Co. v. Arizona ex rel. Sullivan, 325 U.S. 761, 782-83 (1945).

169367 U.S. 497 (1961).

170 Id. at 501-02; 381 U.S. at 505-06 (White, J., concurring).

171367 U.S. at 512-13 (Douglas, J., dissenting).

172381 U.S. at 506. See Poe v." Ullman, 367 U.S. at 502: "The undeviating policy [of nonenforcement] throughout all the long years .. bespeaks more than prosecutorial paralysis"; A. BICKEL, supra note 71, at 152-56.

173 Carolene Products Co. v. United States, 323 U.S. 18, 31-32 (1944) and cases cited therein; United States v. Carolene Products Co., 304 U.S. 144, 153-54 (1938); South Carolina Hwy. Dep't v. Barnwell Bros., 303 U.S. 177, 191-92 (1938); see Thayer, The Origin and Scope of the American Doctrine of Constitutional Law, 7 HARV. L. REV. 129, 143-44 (1893). 
the social purpose limitation, ${ }^{174}$ but the connotations are misleading. No legislature lacks sanity. ${ }^{175}$ Professor Alexander Bickel has suggested that an irrational decision is one made under the stress of "heightened emotion." 176 But emotion is an inseparable component of all decision making, whether emotion refers to subconscious attitudes formed by earlier experiences or to the impact of endocrine secretions triggered by exciting or disturbing stimuli.

If an immediate response to those stimuli is irrational because it occurs without deliberate consideration of consequences and alternatives, such precipitate action is precluded by the process of legislative enactment, which involves introduction, committee evaluation, discussion, and vote in two houses, followed by executive review. Legislators may respond zealously to disturbing events or popular outcry, but zeal is not inconsistent with the legislative function ${ }^{177}$ nor can its legitimacy be measured by the adrenalin level of the zealots. The constitutional isste concerns the consequences of enacted policy, not the personal feelings of the legislators.

An irrational response is manifestly inappropriate to the stimulus, and emotional responses are not manifestly inappropriate per se. Irrational legislation is manifestly inappropriate legislation, and legislation that serves no socially useful purpose is manifestly inappropriate. In this sense regulations lacking social purpose or effective method are irrational. But that characterization serves no socially useful purpose.

\section{Appraisal of Particular Applications}

Particular regulatory applications that do not implement the regulatory goal lack social purpose. The drowning prevention purpose of the Hempstead excavation ordinance, for example, was not significantly implemented by application of the ordinance to inhibit further deepening of Goldblatt's pond, already 25 feet deep, although application of the ordinance to inhibit deepening of shallow ponds would implement that purpose. ${ }^{178}$

Due process restrictions on choice of law also illustrate this function of the social purpose limitation. The Supreme Court has

174 See M. Weber, The Theory of Social and Economic Organization 115-18 (T. Parsons ed. 1947) ; Solomon, "This New Fetish for Indigency", Justice and iPoverty in an Affuent Society, 66 Covum. L. REv. 248, 260 (1966); Note, A Trial Judge's Freedom and Responsibility in Administering Probation, 71 'Y YLE L.J. 551, 553 (1962).

175 See The Legal Conscience-Selected Papers of Felix S. Cohen 44 (L. Cohen ed. 1960).

178 A. Bickel, The Least Dangerous Branch 41 (1962).

177 Cf. A. BICKET, supra note 176 , at 39-41.

178 See notes 147-50 supra and accompanying text. Substantial deepening of shallow ponds would significantly increase the drowning hazard. 
indicated that the due process clause permits the application of a forum dispute-resolving rule, rather than the rule of another state connected with the dispute through parties, events, or property, only when the forum has an "interest" in that application. ${ }^{179}$ By implication a forum may not apply the rule of any state that lacks an interest. ${ }^{180}$ A state has such an interest when application of its rule implements the purpose of the rule. ${ }^{181}$

Thus, when an injured plaintiff seeks recovery from a bar owner for excessive sale of drinks to the injury-causing driver, any forum should apply a liability rule of the state where the bar is located and the owner resides rather than a nonliability rule of the state where the accident occurred and plaintiff resides. ${ }^{182}$ The bar state's purpose of deterring excessive liquor sales to persons using its highways will be implemented by the application of its rule; ${ }^{183}$ the plaintiff state's

178 Clay v. Sun Ins. Office, 377 U.S. 179 (1964) ; Watson v. Employers Liability Assurance Corp., 348 U.S. 66 (1954) ; Hoopeston Canning Co. v. Cullen, 318 U.S. 313 (1943) ; see Pacific Employers Ins. Co. v. Industrial Accident Comm'n, 306 U.S. 493 (1939), and Carroll v. Lanza, 349 U.S. 408 (1955), speaking primarily in terms of full faith and credit; cf. Alaska Packers Ass'n v. Industrial Accident Commission, 294 U.S. 532 (1935) ; Crider v. Zurich Ins. Co., 380 U.S. 39 (1965). See also Pearson v. Northeast Airlines, Inc., 309 F.2d 553 (2nd Cir. 1962) ; B. CurRIE, SeLECTED EsSays on THE CONFLICT of Laws 188 (1963). As yet, however, no modern Supreme Court case has precluded application of forum law on this ground. A suffcient forum interest has been found in every such case presenting the issue. $C f$. First National Bank v. United Airlines, Inc., 342 U.S. 396 (1952); Hughes v. Fetter, 341 U.S. 609 (1951) ; Order of United Commercial Travelers v. Wolfe, 331 U.S. 586 (1947).

180 See cases cited note 179 supra; B. CURRIE, supra note 179 , at 196-97; REStatement (Second) of Conflict of Laws 20 (Tent. Draft No. 3, 1966). As yet, no Supreme Court case has precluded application of non-forum law on this ground. See Young v. Masci, 289 U.S. 253 (1933). The full faith and credit clause limits the rejection, not the application, of non-forum law.

181 See cases cited note 179 supra; D. Cavers, The Choice of Law Process 98-102 (1965) ; B. CURRIE, supra note 179.

182 Cf. Schmidt v. Driscoll Hotel, Inc., 249 Minn. 376, 82 N.W.2d 365 (1957). "Dram Shop" statutes commonly impose a secondary liability upon the bar owner; the negligent drunk driver is primarily liable but may lack sufficient insurance and resources to pay the damages.

The judicial jurisdiction of the bar owner's state is obvious. The plaintiff's state can exercise jurisdiction if the bar owner is served there, owns property located there, carries insurance with a company that has headquarters and is subject to "direct action" there, or generally appears in the action; and perhaps the bar owner can be reached by a long-arm jurisdictional statute. See, e.g., WIS. STAT. ANN. \$262.05 (Supp. 1967) ; Mont. R. Crv. Pro. 4B.

183 The drunk must, of course, drive on local roads to reach an adjacent state. Each state ordinarily regulates to promote the welfare of the people who live or carry on business within the state. Most tort rules reflect a policy of deterring anti-social conduct in the state as well as a policy of loss allocation that provides security for innocent injured residents. Deterrence is particularly significant when, as here, the tortfeasor (bar owner) can effectively control the anti-social conduct. In the presence of liability insurance, deterrence results from the impact of loss experience on premiums and insurability, from the threat of a judgment in excess of the coverage, and from the possible inconvenience and loss of working time that usually accompanies litigation. In addition, litigation may trigger license suspension proceedings, particularly when the accident is out-of-state and not likely otherwise to come to the attention of the bar owner's state officials. The loss-allocation policy of the bar owner's state is not implemented by application of its liability rule when the injured plaintiff resides in a state with a nonliability rule. 
purpose of insulating local bar owners from an oppressive responsibility, stimulating local economic activity, and perhaps holding down the local price of drinks, will not be implemented by application of its rule. The plaintiff-state rule reflects socially useful purposes and provides a method (nonliability) that usually implements those purposes, but they are not implemented by application of the rule to a suit against a bar owner of another state. The social purpose limitation protects a litigating party from adverse regulation by a state whose policy is not thereby implemented.

\section{The Less Intrustve Alternative Corollary}

The due process-social purpose requirement is not necessarily satisfied by every regulation that implements a socially yseful purpose. The implications of the requirement are broader. If government should restrict human activity only to implement a socially useful purpose, government should restrict human activity no more than necessary to implement that purpose!. The intrusion should be minimal. A greater restriction is not socially useful when a lesser one will do the job. Regulatory and individual autonomy values are accommodated by the less intrusive, or less restrictive, alternative.

Like the basic social purpose limitation, this less intrusive alternative corollary has supported the invalidation of regulations found to impair more specific values derived from constitutional or nonconstitutional sources. ${ }^{184}$ But the Supreme Court has been reluctant to accept it as an independent due process limitation. ${ }^{185}$

\section{Judicial Recognition: Regulations Affecting Interstate Commerce}

State health and safety regulations have been invalidated as obstructions to interstate commerce when less obstructive regulatory methods were available. But the due process clause was rejected as a basis for invalidation of such unnecessarily restrictive regulations although their social purposes were vitiated by the alternatives. A city ordinance forbidding the sale of milk produced beyond the twenty-five mile radius of local inspection was invalidated in Dean Milk Co. v. City of Madison ${ }^{186}$ because the regulatory purpose of insuring a pure milk supply could be effectively implemented by the less restrictive alternative of sending local inspectors, and charging the added costs,

184 See generally Brown, Due Process, Police Power, and the Suprente Court, 40 HARv. L. REv. 943, 952-56 (1927); Struve, The Less-Restrictive Alternative Principle and Economic Due Process, 80 Harv. L. REv. 1463 (1967); Wormuth \& Mirkin, The Doctrine of the Reasonable Alternative, 9 UTAB L. REv. 254 (1964).

185 Cf. Brown, supra note 184, at 956; Struve, supra note 184, at 1463; Wormuth \& Mirkin, supra note 184, at 296.

186340 U.S. 349 (1951). The ordinance also excluded milk pasteurized more than five miles from the city center. $C$ f. Breard v. Alexandria, 341 U.S. 622 (1951). 
to out-of-state milk producers. ${ }^{187}$ That solution accommodated the commerce clause-free market value and the local health value. But the Court denied that the same considerations would invalidate the ordinance on due process grounds, stating:

A different view, that the ordinance is valid simply because it professes to be a health measure, would mean that the Commerce Clause of itself imposes no limitations on state action other than those laid down by the Due Process Clause .....188

Eight years later the Court invalidated an Illinois requirement that trucks use special contour mudguards rather than the conventional mudflaps permitted or required in forty-five states. ${ }^{189}$ The national interest in unimpeded truck movement ${ }^{190}$ was found to outweigh the state safety interest because the evidence "conclusively" showed that flaps intercept debris as effectively as contour guards. ${ }^{191}$ The less restrictive alternative, ${ }^{192}$ which could have resolved the case alone, was perceived as no more than a reducing agent that made the local benefits lighter than national commerce clause interests.

If there are alternative ways of solving a problem, we do not sit to determine which of them is best suited to achieve a valid state objective....,

said the majority;

Unless we can conclude . . . that "the total effect of the law as a safety measure . . . is so slight ... as not to outweigh the national interest in keeping interstate commerce free from interferences . . ." we must uphold the statute. ${ }^{183}$

Application of the due process limitation was dismissed with the remark:

Local regulations which would pass muster under the Due Process Clause might nonetheless fail to survive other challenges to constitutionality that bring the Supremacy Clause into play [i.e., challenges based upon the federal interstate commerce power.$^{194}$

187 The Court also indicated another alternative: adoption of the Model Milk Ordinance, approved by the Madison Health Commissioner, which allows production state inspectors to certify compliance with importing state standards, subject to verification by the United States Public Health Service. 340 U.S. at 355-56.

188340 U.S. at 354; cf. South Carolina State Highway Dep't v. Barnwell Bros., 303 U.S. 177 (1938).

$180 \mathrm{Bibb}$ v. Navajo Freight Lines, Inc., 359 U.S. 520 (1959).

190 Because a nearby state required flaps, a truck could not operate in both states without a costly and time-consuming change of equipment.

101359 U.S. at 525.

192 A regulation permitting either contour guards or flaps is clearly less restrictive. 103359 U.S. at 524 .

104 Id. at 529. 


\section{Iudicial Recognition: Regulations Affecting Constitutionally Sheltered Activity}

Speech-limiting regulations have been invalidated because less intrusive methods were available to implement the regulatory purpose, but the rationale has been applied as an aspect of the speech protection, not as an independent due process ground for invalidation. ${ }^{195}$

Overbroad speech regulations are disapproved because they restrict constitutionally sheltered communication more than necessary to implement their purpose.

Any abuses which loud-speakers create can be controlled by narrowly drawn statutes [regulating decibels and the hours and place of public discussion] said a majority of five in Saia $v$. New York; ${ }^{198}$

[w] hen a city allows an official to ban them in his uncontrolled discretion, it sanctions a device for suppression of free communication of ideas.

Dismissal of public school teachers who fail to list annually every organization to which they have belonged or regularly contributed within five years inhibits " $[\mathrm{m}]$ any . . . relationships [that] could have no possible bearing upon the teacher's occupational competency or fitness," declared a similar majority in Shelton $v$. Tucker. ${ }^{197}$

[E]ven though the governmental purpose be legitimate and substantial, that purpose cannot be pursued by means that broadly stifle fundamental personal liberties when the end can be more narrowly achieved. The breadth of legislative abridgment must be viewed in the light of less drastic means 'for achieving the same basic purpose. . . . ${ }^{108}$

The statute's comprehensive interference with associational freedom goes far beyond what might be justified 199

And welfare regulations that inhibit religious observance are invalid unless the state "demonstrate[s] that no alternative forms of regulation would combat [the] abuses without infringing First Amendment rights." 200

195 See Struve, supra note 184, at 1487; Wormuth \& Mirkin, supra note 184, at 292, 296.

196334 U.S. 558, 562 (1948); cf. Kovacs v. Cooper, 336 U.S. 77 (1949).

197364 U.S. 479,488 (1960).

198 Id. at 488 (emphasis added).

199364 U.S. at 490. See also Keyishian v. Board of Regents, 385 U.S. 589 (1967); Elfbrandt v. Russell, 384 U.S. 11 (1966); NAACP v. Alabama, 377 U.S. 288 (1964); NAACP v. Button, 371 U.S. 415 (1963); Cantwell v. Connecticut, 310 U.S. 296 (1940); Thornhill v. Alabama, 310 U.S. 88 (1940).

200 Sherbert v. Verner, 374 U.S. 398, 407 (1963). 
Vague regulations, many restricting speech, have traditionally been invalidated because they provide neither fair warning of proscribed conduct nor an ascertainable standard of guilt for adjudicators, or because free expression is inhibited by the resulting uncertainty. ${ }^{201}$ Although such invalidation connotes the availability of less intrusive alternatives, ${ }^{202}$ that rationale has not been explicitly articulated.

[A] statute which . . . forbids . . . the doing of an act in terms so vague that men of common intelligence must necessarily guess at its meaning and differ as to its application, violates the first essential of due process of law, ${ }^{203}$

the Court declared in 1926 and reiterated in 1961.204 But men of common intelligence can avoid areas of unclear as well as clear application, ${ }^{205}$ and ambiguities can be clarified in declaratory and injunctive actions. Vague regulations violate due process because the area of uncertain regulatory application that inhibits permissible activity can be reduced by a less restrictive formulation specifying in greater detail the nature of the proscribed conduct. ${ }^{206}$

The availability of less intrusive alternatives has also supported the rejection of regulations perceived as impairing fundamental rights derived from nonconstitutional sources. Invalidation of passport regulations found to infringe the "right to travel" was supported in Apetheker v. Secretary of State by the availability of a less intrusive alternative that would relate passport revocation to unlawful travel plans rather than to Communist Party membership. The Court observed that "Congress has within its power 'less drastic' means of achieving the congressional objective," 207 but emphasized that "freedom of travel is a constitutional liberty closely related to rights of free speech and association." 208

Assertions in Griswold by Justices Douglas and Goldberg that marital fidelity could be safeguarded by a less sweeping regulation,

201 See Keyishian v. Board of Regents, 385 U.S. 589 (1967) ; Baggett v. Bullith, 377 U.S. 360 (1964); NAACP v. Button, 371 U.S. 415 (1963); Cramp v. Board of Pub. Instruction, 368 U.S. 278 (1961); A. BICKEx, supra note 176, at 149-52; Freund, The Supreme Court and Civil Liberties, 4 VAND. L. REv. 533, 540 (1951); Note, The Void-for-V agueness Doctrine in the Supreme Court, 109 U. PA. L. REv. 67, 75-76 (1960).

202 Vagueness may also obscure the social purpose of the regulation.

203 Connally v. General Construction Co., 269 U.S. 385, 391 (1926). See, Cline v. Frink Dairy Co., 274 U.S. 445, 465 (1927).

204 Cramp v. Board of Public Instruction, 368 U.S. 278, 287 (1961).

205 See Nash v. United States, 229 U.S. 373, 377 (1913) (Holmes, J.) ; A. BICKEx, supra note 176, at 151; Note, supra note 201, at 69.

206 . Cf. NAACP v. Button, 371 U.S. 415, 433 (1963) ; A. BICKEL, supra note 176, at 149,151 ; Freund, supra note 201, at 455 ; Note, supra note 201 , at 109.

207 Aptheker v. Secretary of State, 378 U.S. 500, 512 (1964); see text accompanying note 27 supra.

208378 U.S. at 517. 
and Justice White's preference for a contraceptive ban limited to illicit sexual relationships, appear in the context of opinions that identify marital privacy as a fundamental due process right derived from a Bill of Rights penumbra or from nonconstitutional sources. ${ }^{209}$

But when the Court has perceived no infringement of speech or other fundamental rights, the less intrusive alternative rationale has not been applied. Summary expulsion of a civilian cook from a naval plant on security grounds was upheld in Cafeteria Workers $v$. McElroy 210 because the expulsion denied no more than an "opportunity to work at one . . military installation" and did not "bestow a badge of disloyalty or infamy." 211 Notice of charges and a hearing were not recognized as a less intrusive method of eliminating security risks. ${ }^{212}$

\section{Judicial Recognition: Economic Regulations}

The availability of a less intrusive alternative occasionally added weight to the impairment of free enterprise values at a time when due process was measured by the gravitational difference between such impairment and the public benefits of regulation. ${ }^{213}$ Thus, a ban on private employment agencies was invalidated in Adams $v$. Tanner ${ }^{214}$ with this observation:

Because abuses may . . . grow up in connection with this business, is adequate reason for hedging it about by proper regulations. But this is not enough to justify destruction of one's right to follow a distinctly useful calling in an upright way . . . 215

But when benefits outweighed free enterprise impairment, less restrictive methods became irrelevant. In the same year corporate securities regulation was upheld with the comment:

It may be that there are better ways to meet the evils at which the statute is directed and counsel have felt it in-

209381 U.S. at $485,499$.

210 Cafeteria \& Restaurant Workers Union v. McElroy, 367 U.S. 886 (1961). 211 Id. at 898 .

212 Cf. Slochower v. Board of Higher Educ., 350 U.S. 551, 558 (1956) (fifth amendment self-incrimination values reflected by decision that due process was denied state college professor dismissed without hearing after invoking self-incrimination privilege) ; Skinner v. Oklahoma, 316 U.S. 535, 544 (1942) (Stone, C.J., concurring) (perhaps accepting the less intrusive alternative rationale as an independent due process standard).

213 See Brown, supra note 184, at 954-56; cf. Lawton v. Steele, 152 U.S. 133, 137 (1894); Struve, supra note 184, at 1464; Wormuth \& Mirkin, supra note 184, at 263-67. 214244 U.S. 590 (1917).

215 Id. at 594. Justices Brandeis, Holmes, and Clarke dissented. See also Liggett Co. v. Baldridge, 278 U.S. 105 (1928). 
cumbent upon them to suggest a better way. We can only reply that it is not our function to decide between measures and upon a comparision of their utility and adequacy determine their legality. ${ }^{216}$

The availability of a less intrusive alternative was perhaps the sole ground for decision in Weaver $v$. Palmer Brothers Co. ${ }^{217} \mathrm{~A}$ ban on bedding manufactured from used material was there invalidated because health hazards and deception were precludable by low cost sterilization and labeling. The Court nevertheless referred to constitutional protection of "property rights" and emphasized that bedding materials are "useful articles . . . to be distinguished from things that the State is deemed to have power to suppress as inherently dangerous." 218

The Weaver bud did not bloom. Most of the later economic due process cases ignore the less intrusive alternative, and some appear to reject the concept by almost total deference to the legislative choice of method as well as purpose. ${ }^{219}$ Exclusion from interstate commerce of evaporated skim milk enriched with vegetable oil and vitamins,

218 Merrick v. N. W. Halsey \& Co., 242 U.S. 568, 589 (1917).

217270 U.S. 402 (1926). Without articulating the principle, Jay Burns Baking Co. v. Bryan, 264 U.S. 504 (1924) may also have rested solely upon the availability of a less intrusive alternative. The Court there invalidated a requirement that commercial bread loaves not exceed by more than two ounces prescribed minimum weights, because compliance was difficult unless the bread was wrapped to control evaporation; unwrapped bread was in strong demand; purchasers would not likely take an intermediate weight loaf for a heavier loaf [ [ ], and "short weights readily could have been dealt with in a direct and effective way." Id. at 516-17. Justice Brandeis, dissenting, demonstrated that the excess weight limitation was necessary for effective administration of an anti-short-weight policy. Id. at 520-27.

218 Id. at 412-13. Justice Holmes, joined by Justices Brandeis and Stone, dissented because:

The Legislature may have been of the opinion ... that the actual practice of filling comfortables with unsterilized shoddy ... was wide spread. . . It is admitted to be impossible to distinguish the innocent from the infected product in any practicable way, when it is made up into comfortables.... If the legislature regarded the danger as very great and inspection and tagging as inadequate remedies ... in order to prevent the spread of disease it constitutionally could forbid any use of shoddy for bedding ...."

Id. at 415. But the dissenters did not mention the low cost of sterilization nor acknowledge that the difficulty of detecting enclosed, used material indicates the need for effective, pre-enclosure inspection to inhibit evasion of either regulation. See text accompanying note 241 infra. This dissent reflects a preference for judicial deference to legislative methods over judicial appraisal of alternatives. See also Adams v. Tanner, 244 U.S. 590, 599-600 (1916) (Brandeis, J., joined by Holmes \& Clarke, JJ., dissenting); United States v. Carolene Products Co., 304 U.S. 144, 152 (1937).

219 See Struve, supra note 184; Wormuth and Mirkin, supra note 184, at 266; Hetherington, supra note 19, at 23-28. But see Daniel v. Family Security Life Ins. Co., 336 U.S. 220, 225 (1949), distinguishing Liggett Co. v. Baldridge, 278 U.S. 105 (1928), on the ground that "[t] adapted to the recognized evil than the provision now before us." 
admittedly as nutritious as whole milk, was upheld in Carolene Products Co. $v$. United States ${ }^{220}$ as a congressionally designed protection against possible consumer deception despite truthful labeling. Weaver was distinguished on the ground that "[s]terilization, inspection and labeling were [there] deemed to be sufficient to negative the possibilities of . . . evils." ${ }^{221}$ Yet no consideration was given to a less intrusive requirement that containers have a distinctive size, shape, and color, with emphatic labeling, perhaps in several languages. ${ }^{222}$ Instead, the congressional choice of method was considered unassailable if "rational." 223

A state requirement that all employees be given four hours off with pay to vote was upheld in Day-Brite Lighting, Inc. v. Missouri ${ }^{224}$ because:

220323 U.S. 18 (1944).

The process of manufacture consists of taking natural whole milk, extracting the butterfat content and then adding cottonseed or cocoanut oil and fish liver oil, which latter oil contains vitamins $A$ and $D$. The process includes pasteurization of the milk, evaporation, homogenization of the mixture and sterilization. The compound is sold under various trade names in cans of the same size and shape as those used for evaporated milk. The contents of the can are practically indistinguishable by the buying public from evaporated whole milk, but the cans are truthfully labelled to show the trade names and the ingredients.

Id. at $20-21$.

Cf. United States v. Carolene Products Co., 304 U.S. 144 (1937) (involving evaporated skim milk not enriched with vitamins); Hebe Co. v. Shaw, 248 U.S. 297 (1919).

221323 U.S. at 29.

222 By contrast, a state proscription on the retail sale of evaporated skim milk was invalidated by the New York Court of Appeals expressly on the less intrusive alternative ground, although the opinion refers to "the right to sell non-deleterious substances." Defiance Milk Products Co. v. Du Mond, 309 N.Y. 537, 132 N.E.2d 829 (1956). The court stated:

.. the property of a citizen including his right to sell non deleterious substances may not be taken from him without rhyme or reason .... [A] wholesome and useful food product has by statute been excluded from sale in this State. The ostensible legislative purpose was to see to it that customers did not get evaporated skimmed milk. But plaintiff's labels plainly said: "Evaporated Skimmed Milk." If more distinctive marking was thought necessary, the Legislature could have demanded other kinds of labels or special sizes, shapes or colors of containers.

Id. at 541,132 N.E.2d at $830-31$.

223323 U.S. at 31-32. Since fortified evaporated skim milk has the appearance, taste, and nutrient value of evaporated milk, see note 220 supra, the antideception values underlying the legislation must be concerned with education of consumers and with protecting the psychological preference of some for "natural" milk. But the Court seems to suggest that the legislation protects consumers from being persuaded to buy an inferior product. "Although ... f filled milk compounds as enriched are equally wholesome and nutritious as milk with the same content of calories and vitamins," said Justice Reed, "they are artificial or manufactured foods which are cheaper to produce than similar whole milk products." 323 U.S. at 23. In identifying the evil, he quotes from the congressional committee report: "Filled milk is sold under various trade names... Storekeepers sell it with the statements that it takes the place of milk,' 'just as good as condensed and much cheaper,' 'nothing better on the market,' 'takes the place of condensed milk." " Id. at 23 n.6.' The Court appears to have been oblivious to the speech values impaired by legislative disapproval of truthful communications.

224342 U.S. 421 (1952). 
[T] he state legislatures . . may within extremely broad limits control practices in the business-labor field, so long as specific constitutional prohibitions are not violated ... ${ }^{225}$

The present law . . . is designed to eliminate any penalty for exercising the right of suffrage and to remove a practical obstacle to getting out the vote. ${ }^{228}$

Ignored were such alternatives as later polling hours and a shorter time-off period adequate for voting while en route to or from work.

The statement in Goldblatt v. Town of Hempstead that "we . . . need to know such things as . . . the availability and effectiveness of other less drastic protective steps [than application of the antiexcavation ordinance to Goldblatt's deep pond]" ${ }^{227}$ indicates the significance of less intrusive alternatives; but no consideration was given to enclosure, slope, and berm requirements, fully met by Goldblatt, as an effective, less drastic method of reducing the drowning hazard. ${ }^{228}$

\section{The Indicia of Less Intrusive Alternatives}

Courts can identify less intrusive methods by comparing the restrictiveness, effectiveness, and cost of a regulation and suggested alternatives. But deference is due the legislative choice unless the alternative clearly is less restrictive and within the same range of effectiveness and cost. ${ }^{229}$ The legislative role is not usurped by such an appraisal: the court does not reject legislative purposes but suggests constitutionally appropriate ways to achieve them. Legislature and judiciary are engaged in a cooperative undertaking to implement regulatory and due process values. ${ }^{230}$

Legislators need not enact a judicially designated alternative or abandon their goal. In response to the decision, they may develop a different method or reaffirm the initial method if scrutiny of the alternative reveals judicially unperceived deficiencies. But a carefully delineated judicial alternative is likely to receive serious legislative consideration.

$225 I d$. at 423 .

228 Id. at 424 .

227369 U.S. at 590. See notes 147-50 supra and accompanying text.

228 The Court suggested that evidence of a few holes burrowed under the fence indicated attractiveness and danger to children. 369 U.S. at 595 . Yet that evidence only pointed to the need for a sturdy enclosure to keep children away from the already deep pond. See note 265 infra and accompanying text.

229 See Struve, supra note 184, at 1471 . See also A. Bicker, supra note 176; Thayer, supra note 173 , at 144 .

230 'Legislative history not infrequently discloses either no substantial consideration of less intrusive alternatives and due process values, or a tacit reference of the constitutional issue to the courts. And the absence of legislative histories obscures the legislative process in most states. 


\section{Restrictiveness}

The comparative restrictiveness of a regulation and an alternative usually presents a debatable issue, necessarily resolved by the adoption of the regulation. An alternative that would shift the restraint from one group to another-a proposed alternative freeway route, for example-is seldom clearly less restrictive.

But alternative methods are often indisputably less restrictive when tailored to fit more closely the regulatory goals. Truck movement manifestly is impeded less by conventional mudflaps than by special contour mudguards. ${ }^{231}$ Exclusion of nonlocal milk is manifestly more restrictive than inspection and a small fee at the place of production. ${ }^{232}$ Required sterilization and labeling restrict less than proscription of used bedding materials. ${ }^{233}$ Specification of distinctive containers and emphatic labeling restrict less than proscription of skim milk fortified with vegetable fat. ${ }^{234}$ Payment of wages for two voting hours is less restrictive than payment for four. ${ }^{235} \mathrm{~A}$ ban on the use of contraceptives in illicit relationships is less restrictive than a proscription of all use to avoid conception. ${ }^{236}$

\section{Cost}

The additional public cost of alternatives often is not a significant issue. Nonlocal milk producers pay the added inspection costs. Inspection is needed to exclude used or unsterilized material, deceptive containers or deceptive contents, trucks without mudflaps or without contour guards. Two hours off for voting is less expensive to the community than four hours off.

An alternative that increases public cost implicitly imposes an additional restraint on taxpayers or on those who would benefit from a different allocation of the public funds. But a moderate increase in public expense that does not substantially burden any individual may be socially less restrictive than the assessment of heavy costs to a few individuals who derive no particular advantage from the benefits of the assessment. Longer polling hours are perhaps less restrictive than voting-time payments, even if the polling cost exceeds the price rise resulting from the payments, because full price recoupment is not available to employers with out-of-state or mechanized competitors. ${ }^{237}$

\footnotetext{
231 See notes 190, 192; text accompanying notes 189-94 supra.

232 See text accompanying notes 186-88 supra.

233 See text accompanying notes 217-18 supra.

234 See text accompanying notes $220-23$ supra.

235 See text accompanying notes 224-25 supra.

238 See text accompanying notes 46-66, 154, 168-72, 209 supra.

237 See text accompanying notes 325-31 infra.
} 
Constitutional recognition of increased public cost as a less intrusive alternative is implicit in the requirement of the eminent domain clause that compensation be paid when antiretroactivity and tax-equality values are significantly impaired by a regulatory assessment. ${ }^{238}$

\section{Effectiveness}

Effectiveness suggests a precarious appraisal of causation; yet the effectiveness of alternatives is often clear. Mudflaps were "incontrovertibly" shown to be as effective as concur guards. ${ }^{238}$ The effectiveness of nonlocal milk inspection was not challenged. ${ }^{240}$ Justice Holmes, dissenting in Weaver v. Palmer Brothers Co. ${ }^{241}$ avoided an appraisal of effectiveness by deferring to the ostensible legislative conclusion that sterilization requirements and inspection would not effectively eliminate dirty, used material, which is difficult to detect when enclosed. But effective, pre-enclosure inspection is just as necessary to enforce a ban on all used material as to enforce a ban on dirty used material. And the low sterilization cost, referred to by the majority, ${ }^{242}$ suggests that unsterile bedding would be more effectively eliminated by required sterilization and inspection than by total proscription of inexpensive used material.

Deference was accorded the "rational" legislative ban on fortified evaporated skim milk in Carolene Products Co. v. United States because "the compounds lend themselves readily to substitution for or confusion with milk products." 243 Yet consumers preferring the more expensive evaporated whole milk could be effectively protected from deception by distinctive containers and emphatic labeling in several languages. ${ }^{244}$ And would not two hours off with pay eliminate employment obstacles to voting? ${ }^{245}$

238 U.S. Const. amend. V. See text accompanying notes 325-31 infra; cf. text accompanying notes $322-24$ infra.

239 See note 191 supra and accompanying text.

240 Nor was there any challenge to the effectiveness of the Model Milk Ordinance, advocated as an alternative by the city health officer. See note 187 supra.

241270 U.S. 402, 415-16 (1926) ; see note 218 supra.

242270 U.S. 402,411 (1926).

243323 U.S. 18, 22-23 (1944).

244 See note 222 supra.

245 See text accompanying notes 224-26 supra. But the clear effectiveness of longer polling hours can be ascertained only by a canvassing of the evidence.

In Goldblatt, the Court suggested no reason why a ban on further excavations from a deep pond added to the effectiveness of the drowning protections provided by enclosure, slope, and berm requirements. See notes 147-50, 228 supra and accompanying text. 
By contrast, no clearly effective, less restrictive alternatives were available to implement the purposes of employment agency, debt adjuster, and right-to-work regulations. ${ }^{246}$

A less restrictive alternative cannot be less effective than a regulation shown to be substantially unenforceable. ${ }^{247}$ The Connecticut contraceptive ban could scarcely implement its purpose less effectively if limited to illicit sexual relationships, a limitation which Justice White suggested "would serve the end posited by Connecticut . . . with the same effectiveness, or ineffectiveness, as the broad anti-use statute . . .." 248 And is a statute directly forbidding adultery and fornication any less effective?

\section{Non-Formal Alternatives}

Less intrusive alternatives need not take the form of regulations. A non-formal social mechanism may effectively implement the purpose of a more restrictive governmental directive. The clear and imminent danger requirement for speech-inhibiting regulation recognizes community discussion intervening between speech and action as an effective, less intrusive method of interdicting nonimminent harm. ${ }^{249} \mathrm{Re}-$ cently, two justices have suggested that reply by public officials in the communications media is an effective defamation remedy less chilling to speech than an action for damages. ${ }^{250}$

246 See Ferguson v. Skrupa, 372 U.S. 726 (1963); Lincoln Federal Labor Union v. Northwestern Iron \& Metal Co., 335 U.S. 525 (1949); Olsen v. Nebraska ex rel. Western Reference \& Bond Ass'n, 313 U.S. 236 (1941).

247 See text at notes 169-72 supra.

248381 U.S. 479, 507 (1965) (emphasis added).

249 That the necessity which is essential to a valid restriction does not exist unless speech would produce, or is intended to produce, a clear and imminent danger of some substantive evil which the State constitutionally may seek to prevent has been settled ....

Whitney v. California, 279 U.S. 357, 373 (1927) (Brandeis, J., concurring).

[T]he fitting remedy for evil counsels is good ones.

Id. at 375 .

. . If there be time to expose through discussion the falsehood and fallacies, to avert the evil by the processes of education, the remedy to be applied is more speech, not enforced silence. Only an emergency can justify repression.

Id. at 377 .

See also Gitlow v. New York, 268 U.S. 652, 672 (1925) (Holmes \& Brandeis, JJ, dissenting); Abrams v. United States, 250 U.S. 616, 624 (1919) (Holmes, J., dissenting); Schenck v. United States, 249 U.S. 47 (1919).

This doctrine, when applied, has provided opportunities for testing the effectiveness of community discussion as a non-formal alternative. See text accompanying notes 333-35 infra. See also note 250 infra (last paragraph).

250 New York Times Co. v. Sullivan, 376 U.S. 254, 304-05 (1964) (Goldberg, J., concurring, joined by Douglas, J.) :

The conclusion that the Constitution affords the citizen and the press an absolute privilege for criticism of official conduct does not leave the public 
A combination of formal and non-formal social mechanisms probably provides a less intrusive alternative for implementing the social policies that underlie restrictions on contraceptives, fornication and adultery. The purpose of forbidding contraceptives is to inhibit fornication and adultery. ${ }^{251}$ The purpose of forbidding fornication is to inhibit illegitimacy, venereal disease, avoidance of marriage, and adolescent emotional instability. But the incontrovertible lack of community inclination and capacity to enforce this pervasive restraint on a physiological drive, and the consequent threat of selective, arbitrary enforcement, suggest a clearly less restrictive and no less effective alternative: easily available contraceptives and birth control information, venereal-disease and sex education, counseling and public health services, and the social pressure and psychological need to marry. An additional purpose of the adultery proscription is to inhibit family disruption, but the same incapacity for enforcement suggests that widely-available marriage counseling is clearly less restrictive and no less effective. ${ }^{252}$

\section{Proof Concerning Soctal Purpose}

Application of the social purpose limitation involves appraisal of evidence concerning regulatory purpose, social need and social structure, and the physical and psychological responses that underlie methodology. Such evidence is drawn from observed or recorded community experience, and its sources include accumulated judicial perceptions, as well as testimony, writings, and demonstrations. It is frequently introduced at both the trial and the appellate level in the form of argument suggesting inferences to be drawn from judicial

official without defenses against unsubstantiated opinions or deliberate misstatements. "Under our system of government, counter-argument and education are the weapons available to expose these matters, not abridgement tion ar free speech . . "Wood v. Georgia [citation omitted]. The public official certainly has equal if not greater access than most private citizens to media of communication.

The majority perceived the first amendment as barring actions for nonmalicious, but not for malicious, defamation of public officials, despite the speech-inhibiting effect of both actions, and did not identify the opportunity to reply as a less intrusive alternative, available to counter either kind of defamation. See also Garrison v. Louisiana, 379 U.S. 64 (1964) (applying the same limitation to criminal prosecutions for defamation of public officials). These decisions provide an opportunity for testing the effectiveness of the non-formal alternative. See text accompanying notes 333-37 infra.

The presence of constitutional speech values permits a broader judicial appraisal of less intrusive alternatives in these cases. See text at note 321 infra. They here illustrate that non-formal social mechanisms may provide such alternatives.

251 See notes 154, 168 supra, and 310 infra, and accompanying text.

252 Premarital chastity and marital fidelity, per sese, are probably religious, not social, values. 
observations and published writings. ${ }^{253}$ Sometimes it is a product of judicial research. ${ }^{254}$ Because "social facts" ${ }^{255}$ describe community mechanisms relevant to constitutional limitations, rather than disputed events relevant to a single private controversy, their ascertainment through litigation is the function not of an ad hoc jury or one trial judge but of the judiciary and ultimately of the United States Supreme Court.

The canvassing of such evidence is often labeled judicial notice, ${ }^{256}$ but the process involves more than recognition of incontrovertible general information or identification of special presumptions and inferences that allocate the burden of coming forward with contrary evidence. ${ }^{257}$

Where the existence of a rational basis for legislation whose constitutionality is attacked depends upon facts beyond the sphere of judicial notice, such facts may properly be made the subject of judicial inquiry . . . and the constitutionality of a statute predicated upon the existence of a particular state of facts may be challenged by showing to the court that those facts have ceased to exist. ${ }^{258}$

The questionable hearsay limitation upon evidentiary use of learned treatises ${ }^{259}$ has not been applied to exclude written evidence

253 See Griswold v. Connecticut, 381 U.S. 479 (1965); Poe v. Ullman, 367 U.S. 497 (1961) ; Bibb v. Navajo Freight Lines, Inc., 359 U.S. 520 (1959) ; Brown v. Board of Educ., 347 U.S. 483 (1954) ; FTC v. Ruberoid Co., 343 U.S. 470,485 (1952) (Jackson, J., dissenting); Dean Milk Co. v. Madison, 340 U.S. 349 (1951) ; Southern Pac. Co. v. Arizona, 325 U.S. 761 (1945) ; Muller v. Oregon, 208 U.S. 412 (1908); Jacobson v. Massachusetts, 197 U.S. 11 (1905) ; United States v. Roth, 237 F.2d 796, 802, 812-17 (2d Cir. 1956); Durham v. United Śtates, 214 F.2d 862 (D.C. Cir. 1954); see also C. Aumrrach, L. Garrison, W. Hurst, \& S. Mermin, The Legal Process 91-137 (1961) and authorities there collected; M. CoHEN, LAW AND THE SOCTAL ORDER 186-87 (1933); Karst, Legislative Facts in Constitutional Litigation, 1960 Sup. CT. REv. 75 ; Bikle, Judicial Determination of Questions of Fact Affecting the Constitutional Validity of Legislative Action, 38 HARv. L. REv. 6 (1924); Note, Social and Economic Facts-Appraisal of Suggested Techniques for Presenting Them to the Courts, 61 HARv. L. REv. 692 (1948).

254 FTC v. Ruberoid Co., 343 U.S. 470 (1952); United States v. Roth, 237 F.2d 796, 801 (2d Cir. 1956) (Frank, J., concurring), aff'd on other grounds, 354 U.S. 426 (1957); Note, supra note 253.

255 See Note, supra note 253.

2569 J. WTGMORE, EVIDENCE §2555d (3d ed. 1940). See generally authorities cited supra note 253 .

257 For general discussions of the function of judicial notice, see J. MAGUIRE, J. Weinstern, J. Ceanbourn \& J. Mansfield, Cases and Materials on Evidence 8-84 (5th ed. 1965) [hereinafter cited as MAGUIRE]; C. MCCoRMICK, EvIDENCE 687-712 (1954) ; Davis, Judicial Notice, 55 Colun. L. Rev. 945 (1955) ; McCormick, Judicial Notice, 5 VAND. L. Rev. 296 (1952) ; Morgan, Judicial Notice, 57 HaRv. L. Rev. 269 (1944).

258 United States v. Carolene Products Co., 304 U.S. 144, 153 (1938).

259 Admission of learned treatises has increasing support. See, e.g., Ruth v. Fenchel, 21 N.J. 171, 121 A.2d 373 (1956); MAGUIRE 538-39; Dana, Admission of Learned Treatises in Evidence, 1945 WIS. L. REv. 455; Uniform Rules of Evidence $63(31)$. 
of social facts relevant to constitutionality. ${ }^{260}$ The importance of crossexamination hardly justifies exclusion of accumulated human knowledge written down by persons not available to testify. If the adversely affected party has notice of such evidence and an opportunity to reply, the cogency of the statements and the competence of the authors may be countered by argument, by contrary writings, and by the testimony of experts. ${ }^{261}$ The possible infirmities of jury consideration are not present in such judicial evaluation.

An inference of probable validity drawn from the fact of legislative enactment requires the party attacking a regulation to produce convincing evidence that the regulatory intrusion lacks social purpose. To surmount the burden thus imposed by this "presumption of constitutionality," the attacker must negate facts that would otherwise be assumed in support of the regulation. ${ }^{262}$

Such proof sometimes consists of a suggested inference drawn from experience that the regulatory method will not implement the regulatory purpose or that a less intrusive method is available. Such an inference provided evidence in Griswold that marital infidelity is not discouraged by a ban on the use of contraceptives to prevent conception but not disease. ${ }^{263}$ The New York Court of Appeals responded to such an inference in Defiance Milk when it said:

Appellant argues that plaintiff failed to carry the burden of proof. We do not agree. All plaintiff had to show was that no reasonable basis existed for an absolute ban against

260 See authorities cited note 253 supra.

261 See Wyzanski, A Trial Judge's Freedom and Responsibility, 65 HARv. L. Rev. 1281, 1295-96 (1952); Note, supra note 253, at 697-98; cf. Currie, Appellate Court's Use of Facts Outside of the Record by Resort to Judicial Notice and Independent Investigation, 1960 WIs. L. Rev. 39 (1960) ; Davis, An Approach to Problems of Evidence in the Administrative Process, 55 HARv. L. REv. 364, 402-06 (1942).

Perhaps such notice and opportunity should also be given other persons and institutions significantly concerned with the validity of the regulation.

262 "[W] here the legislative judgment is drawn in question, [inquiry] must be restricted to the issue whether any state of facts, either known or which could reasonably be assumed affords support for it." United States v. Carolene Products Co., 304 U.S. 144, 154 (1937) (emphasis added). See also Bibb v. Navajo Freight Lines, Inc., 359 U.S. 520, 524 (1959) ; Salsburg v. Maryland, 346 U.S. 545 (1954); South Carolina State Highway Dep't v. Barnwell Bros., Inc., 303 U.S. 177, 190-96 (1938) ; Borden's Farm Products Co. v. Baldwin, 293 U.S. 194, 209 (1934); Note, The Presumption of Constitutionality Reconsidered, 36 CoLUM. L. REv. 283 (1936). For the significance of such a presumption, see note $303 \mathrm{~b}$ infra.

For indications of a "narrower" or a contrary presumption when the regulation apparently infringes Bill of Rights or first amendment values, see Sherbert v. Verner, 374 U.S. 398, 406-09 (1963) ; Thornhill v. Alabama, 310 U.S. 88, 95-96 (1940); Schneider v. New Jersey, 308 U.S. 147, 161 (1939) ; United States v. Carolene Products Co., 304 U.S. 144, 152 n.4 (1938) ; Herndon v. Lowrey, 301 U.S. 242, 243-58 (1937); C. BLACK, THE PEOPLE AND THE CouRT, 217-21 (1960); McKay, The Preference for Freedom, 34 N.Y.U. L. REv. 1182 (1959). But see Kovacs v. Cooper, 336 U.S. 77, 90-96 (1949) (Frankfurter, J., concurring), wherein reference to the "preferred position" of the first amendment is disapproved.

263 See note 168 supra and accompanying text, 
evaporated skimmed milk. Since no one has been able to discover any such basis, requisite proof of unconstitutionality was present .... ${ }^{264}$

But in Goldblatt the Supreme Court did not perceive the evidentiary value of a suggested inference drawn from experience that further deepening of a pond already twenty-five feet deep would not increase the drowning hazard. The Court denied relief to the landowner in part because he did not produce other evidence to support that contention:

Although one could imagine that preventing further deepening of a pond already 25 feet deep would have de minimis effect on public safety, we cannot say that such a conclusion is compelled by facts of which we can take notice . . . . Our past cases leave no doubt that appellants had the burden on "reasonableness." 265

\section{Due Process as a Transposer of Constitutional Values}

The due process clause of the fourteenth amendment has long been the vehicle for extending to the states those Bill of Rights limitations on federal authority considered fundamental. ${ }^{266}$ More recently the state equal protection mandate of the fourteenth amendment has been designated a fundamental safeguard implicit in the fifth amendment due process limitation on federal authority. ${ }^{267}$ The "fundamental" characterization supporting these transpositions is a natural rights classification that creates an invidious distinction between constitutional safeguards. The favored Bill of Rights provisions that limit state authority are "principles of justice... rooted in the traditions and conscience of our people." 268 Equal protection values restrain federal officials because "the concepts of equal protection and due process, both stemming from our American ideal of fairness, are

264 Defiance Milk Products Co. v. Du Mond, 309 N.Y. 537, 541-42, 132 N.E.2d 829,831 (1956). See note 222 supra.

265369 U.S. 590, 595-96 (1962). See text accompanying notes 147-50, 227-28, 245 supra. Perhaps expert testimony on the issue would have been helpful, but the town offered no evidence to counter the inference. The presence of equipment may have constituted an added danger, but the Court made no reference to that possibility, and apparently the town did not urge it. Under the circumstances, a remand to the state court for consideration of the issue would not have been inappropriate.

268 See text accompanying notes $33-40$ sipra.

267 Bolling v. Sharpe, 347 U.S. 497 (1954); Korematsu v. United States, 323 U.S. 214, 216 (1944) ; Hirabayashi v. United States, 320 U.S. 81, 100 (1943) ; Detroit Bank v. United States, 317 U.S. 329 (1943); Currin v. Wallace, 306 U.S. 1, 13-14 (1939); Erie R.R. v. Tompkins, 304 U.S. 64 (1938) ; Steward Machine Co. v. Davis, 301 U.S. 548, 585 (1937). See also Buchanan v. Warley, 245 U.S. 60 (1917) ; Gibson v. Mississippi, 162 U.S. 565, 591 (1896).

268 Note 33 supra. 
not mutually exclusive." ${ }^{260}$ A majority of the Court apparently is unable to justify the transposition of restraints without resorting to American traditions, conscience, and ideals.

Justice Black and a minority prefer fourteenth amendment absorption of the entire Bill of Rights to selective, natural law incorporation, contending that total incorporation accords with the original understanding of the fourteenth amendment Congress. ${ }^{270}$ But the amendment's ambiguous legislative history does not sustain their burden of persuasion. ${ }^{271}$ The recent cases that extend the due process category to additional Bill of Rights limitations, suggesting a trend toward total incorporation, rely on the fundamental character of the newly transposed protections, not on the original understanding of the fourteenth amendment enacters. ${ }^{272}$

Natural law sources are not needed to support the containment of both federal and state authority by values underlying constitutional restraints on each. Those values are relevant to enforcement of the social purpose limitation. The recognizable community values that constitute social purpose do not include values rejected by the Constitution; constitutional values affect the choice of methods for implementing social purpose.

Recognition that constitutional values are relevant to social purpose does not imply automatic application to each government of limitations on the other. Because federal and state institutional structures differ, the values underlying a restriction on one government are not necessarily implemented by application of that restriction to both. The nondesignated government need not be restricted by a limitation designed to resolve a problem posed only by the functioning of the designated government. The nondesignated government cannot disregard underlying values relevant to its function but is not limited to the constitutionally specified method of implementation when it can implement those values in a different way.

Constitutional delineation of national governmental institutions, amendment procedures, and nation-state jurisdiction reflects values that

269 Bolling v. Sharpe, 347 U.S. 497, 499 (1954).

270 Cases cited note 41 sipra.

271 See T. Ten Broek, The Antrslanery Origins of the Fourteenth AmendMENT (1951); Fairman, Does the Fourteenth Amendment Incorporate the Bill of Rights? The Original Understanding, 2 STAN. L. REv. 5 (1949) ; Graham The "Conspiracy Theory" of the Fourteenth Amendment, 47 YALE L. J. 371 (1938) ; Kadish, supra note 34 , at $340-41 ; c f .2$ W. CROsskey, Politics and the Constitution, chs. XXXI, XXXII (1953); H. Flack, THE Adoption of THE FourteENTH AMENDNENT (1908); Crosskey, Charles Fairman, "Legislative History", and the Constitutional Limitations on State Authority, 22 U. Cer. L. Rev. 1 (1954). See also Brown v. Board of Educ., 347 U.S. 483, 489 (1954); Bickel, The Original Understanding and the Segregation Decision, 69 HARv. L. REv. 1 (1953).

272 Cases cited note 38 supra; see nọte 40 supra. See also notes 37,39 supra. 
are concerned with efficient federal administration and with adjustment of power between an encompassing national authority and its selfreliant components, some once independent. Such values are not significantly implemented by application of those constitutional specifications to internal state governmental structure. Values concerned with effective popular participation in government, which also underlie those specifications, are relevant to state governmental structure but are implemented by the distinctive institutions of each state. ${ }^{273}$

State compliance with the first amendment manifestly implements the underlying values. Effective self-government and imaginative private ordering are obstructed by state as well as federal disruption of the "marketplace of ideas;" ${ }^{274}$ social divisiveness is engendered by federal or state propagation of religious doctrine. ${ }^{275}$ State compliance also clearly implements the values underlying the third amendment's ban on uninvited, peacetime quartering of soldiers; the fourth amendment's protection against unreasonable searches and seizures; the fifth amendment's inhibition on compelled self-incrimination ${ }^{278}$ and government taking of property without compensation; ${ }^{277}$ the sixth amendment's guaranty to an accused of a speedy, public, impartial local trial, with

273 The popular participation values are also reflected by the republican form of government and equal protection clauses (see the reapportionment cases collected in W. LockeART, Y. KAMISAR \& J. ChOPER, supra note 137, at 116-35, 1371-1419), and perhaps may be illuminated in those contexts by reference to the federal structural provisions.

274 "[T] he best test of truth is the power of the thought to get itself accepted in the competition of the market. . . " Abrams v. United States, 250 U.S. 616, 630 (1919) (Holmes, J., dissenting).

Other speech values include preservation of nonviolent outlets for discontent, encouragement of esthetic expression, and protection for privacy of thought. The last value is impaired by compelled transmission or reception of communications and by interference with communications that the recipient finds interesting or enjoyable.

Justice Harlan has suggested that the first amendment speech protection limits federal obscenity regulations more strictly than the fourteenth amendment limits state obscenity regulations, not because application of that protection to the states implements speech values less effectively, but because federal "interest" in such regulation is more "attenuated" than state interest, and because federal regulation has greater impact. Therefore he would "balance" speech values and regulatory values differently when determining the validity of federal and of state obscenity regulations. Roth v. United States, 354 U.S. 476, 503-08 (1957) (dissenting opinion). This position perhaps suggests that the federal interstate commerce and postal powers authorize federal controls on mail content not to effectuate an independent federal obscenity policy but only to protect each state from importation of materials proscribed by its laws. Compare Cleveland v. United States, 329 U.S. 14 (1946); Caminetti v. United States, 242 U.S. 470 (1917); United States v. Hill, 248 U.S. 420 (1919); Hoke v. United States, 227 U.S. 308 (1913); Lottery Cases, 188 U.S. 321 (1903), with Prudential Ins. Co. v. Benjamin, 328 U.S. 408 (1946); Kentucky Whip \& Collar Co. v. Illinois Cent. R.R., 299 U.S. 334 (1937) ; Clark Distilling Co. v. Western Md. Ry., 242 U.S. 311 (1917) ; In re Rahrer, 140 U.S. 545 (1891).

275 See note 306 infra and accompanying text.

276 See notes 97, 99, 102 supra and accompanying text; self-incrimination cases cited note 38 supra.

277 See Pennsylvania Coal Co. v. Mahon, 260 U.S. 393 (1922); Missouri Pac. R.R. v. Nebraska, 164 U.S. 403 (1896); Chicago B. \& Q. R.R. v. Chicago, 166 U.S. 226 (1897). 
assistance of counsel, confrontation of witnesses, and their compulsory attendance; ${ }^{278}$ and the eighth amendment's proscription of excessive bail and cruel and unusual punishments. Exclusion of illegally obtained evidence in all courts deters privacy intrusion, harassment, and brutality by the F.B.I. and local police. ${ }^{279}$ Assistance of counsel is important to a fair criminal trial before a federal or a state tribunal. ${ }^{280}$ A defendant's control of his own defense, protected by the self-incrimination privilege, is disrupted when his failure to testify is subject to comment by either a federal or a state prosecutor. ${ }^{281}$

Federal compliance with the state equal protection mandate manifestly implements the underlying even-handed treatment values. Discontent and violence, nonproductivity and erosion of self-esteem result from badges of inferiority imposed upon a minority by state or federal action. $^{282}$ The restraint on state impairment of contractual obliga-

Concerning double jeopardy, see Palko v. Connecticut, 302 U.S. 319 (1937). If the double jeopardy provision of the fifth amendment precludes an appeal and retrial in federal courts after acquittal of an accused (a limitation imposed by federal statutes since 1789, see United States v. Mersky, 361 U.S. 431, 434-36 (1960); United States v. Sanges, 144 U.S. 310 (1892) ; United States v. More, 7 U.S. (3 Cranch) 159 (1805) ; 18 U.S.C. $\$ 3731$ (1964)), the same values are implemented by denying such authority to state governments, namely, protection of the accused from harassment and superior government resources, conservation of public and private resources, reduction of public and private anxiety, and expeditious resolution of socially disturbing disputes (see text following note 93 supra and text accompanying notes 102-03, 117 supra). Cf. Palko v. Connecticut, 302 U.S. 319 (1937). But see Bartkus v. Illinois, 359 U.S. 121 (1959); Hoag v. New Jersey, 256 U.S. 464 (1958).

278 See notes $94-102$ supra and accompanying text.

279 See Mapp v. Ohio, 367 U.S. 643 (1961); text accompanying notes 117-19 supra. 280 See Gideon v. Wainwright, 372 U.S. 335 (1963); text accompanying notes $98,100,102$ supra. supra.

281 See Griffin v. California, 380 U.S. 609 (1965); text accompanying note 99

A person accused of crime may become confused and frightened under crossexamination. His memory may be faulty with respect to unanticipated collateral matters. He may be subject to impeachment for prior conviction of felony [for commission of anti-social acts, or for poor reputation as to honesty and veracity; his appearance may be displeasing]. Other aspects of his behavior may be unfavorable if revealed. He is therefore accorded the right to elect whether or not he will testify and to defer this election until after the prosecution has made out a prima facie case against him.

Ratner, Consequences of Exercising the Privilege Against Self-Incrimination, 24 U. CHI. L. REv. 472, 487-88 (1957). A defendant is inhibited from revealing most of these reasons to the jury in explanation of his failure to testify. Prosecutorial comment on such failure thus tends to deprive defendant of a meaningful election by making either alternative strongly "prejudicial," that is, likely to be given undue weight by the jury.

282 Equal protection values are concerned with avoidance of violent action by disadvantaged minorities that necessarily lack an adequate electoral remedy or by a disadvantaged majority that is denied effective electoral control; with elimination of the obstacles to cooperative social activity that result from isolation of disadvantaged minorities; with reduction of nomproductive and delinquent behavior through improved living conditions for such groups, and with preservation of human dignity and selfesteem through community recognition that need fulfillment is as important to each individual as to every other individual. Equal protection values are perhaps implicit 
tions ${ }^{283}$ reflects antiretroactivity values that are implemented by a cognate federal limitation, and those values have been judicially recognized as due process restraints on federal authority despite pronouncements that the contract clause is not directed to national action..$^{284}$ In fact, the antiretroactivity values reflected by the eminent domain, ex post facto, and bill of attainder clauses, as well as by the impairment of contracts clause, have long been identified as traditional due process restraints on the authority of both federal and state government. ${ }^{285}$

But structural differences in federal and state judicial institutions may enable the states to implement underlying values without conforming to the fifth, sixth, and seventh amendment requirements of grand jury indictment, jury trial, and limited review of jury fact-finding. Those values are perhaps primarily concerned with preservation of community supervision over an adjudicatory process administered by a powerful national prosecutor and judiciary not directly responsible to the community. ${ }^{286}$ Federal judges are appointed by the President, hold office during good behavior, and sometimes sit in cities distant from the litigants. Early Circuit Court trial judges were often nonresidents of the state of litigation, ${ }^{287}$ as are court of appeals and Supreme Court judges today. United States Attorneys, also appointed by the President and located in the large cities, are subordinate to the Attorney General in the national capital. Grand jury rather than prosecutor accusation and authoritative jury fact-finding inhibit domination of

in the due process-social purpose limitation because they are closely related to the values underlying that limitation, because "equality" proscribes regulatory distinctions that lack social purpose, and because classification is the essence of regulation. The affirmative recognition of equality values in the equal protection clause of the fourteenth amendment confirms their fifth amendment due process application to federal authority, whether or not equality is a special facet of social purpose.

283 U.S. Const. art. I, §10: "No State shall . . . pass any . . . Law impairing the Obligation of Contract..."

284 Perry v. United States, 294 U.S. 330, 349-54 (1935) ; Lynch v. United States, 292 U.S. 571, 580-82 (1934); cf. FHA v. The Darlington, Inc., 358 U..S. 84 (1958); Norman v. Baltimore \& O. R.R., 294 U.S. 240 (1935); Home Bldg. \& Loan Ass'n v. Blaisdell, 290 U.S. 398 (1934). See Hale, The Sitpreme Court and the Contract Clanse, 57 HaRv. L. Rev. pt. 3, 852, 890 (1944):

... [T] here is at least a tendency for the contract clause and the due process clause to coalesce. Although there is no clause expressly forbidding the federal government to pass laws impairing the obligation of contracts, any federal law impairing them in a manner which the Supreme Court deemed unreasonable would doubtless be held to be a deprivation of property without due process, contrary to the Fifth Amendment.

285 See authorities cited notes 14, 284 supra.

286 Community surveillance and information values are implemented by the public trial guarantee. See text at notes 101,118 supra. The values underlying the grand jury and jury provisions are concerned with ensuring fair trials; compelled public participation in judicial decision-making is probably not an independent purpose.

287 See H. Hart \& H. Wechsler, The Federal Courts and the Federat SysTEM $42-47$ (1953). 
criminal and civil law enforcement by such nonlocal and appointed officials.

State trials, on the other hand, since before the adoption of the fourteenth amendment have customarily been held in the vicinity of the dispute before local judges who are elected for limited terms by that community. ${ }^{288}$ Resident state appellate judges, usually subject to electoral review, ${ }^{289}$ are at least no further than the state capitol. Local district attorneys with the power to accuse by information are also elected. The community supervision values preserved in federal proceedings by the grand jury, jury, and limited review directives are thus implemented in state proceedings by electoral surveillance of local judges and prosecutors. ${ }^{290}$ And the pretrial showing of probable cause implicitly required by the grand jury indictment mandate reflects an antiharassment value that is usually implemented in state felony proceedings by a preliminary hearing before an elected local magistrate.

The Supreme Court has recently concluded that the sixth amendment's jury trial guarantee is a fourteenth amendment due process limitation on state criminal procedures because "trial by jury in [serious] criminal cases is fundamental to the American scheme of justice." 291 But in identifying the purpose of the jury trial provision the majority does not differentiate a judiciary permanently appointed by a strong national executive from a judiciary subject to local electoral surveillance. Support for the "fundamental" classification is largely derived from historical antecedents that are relevant to trials conducted by appointed rather than electorally supervised judges. Reference is made to the "protection against arbitrary rule" provided by the jury trial requirements of the English Bill of Rights; ${ }^{202}$ yet that enactment

288 E. Haynes, The Selection and Tenure of Judges 80, 100 (1944) ; A. VanDERBILt, The CHALleNGe OF LAW ReForm 16 (1955); Nelson, Variation on a Theme-Selection and Temure of Judges, 36 CALIF. L. REv. 4, 15-17 (1962). Most state judges are initially appointed to fill a vacancy, and thereafter elected. In a few states judges are selected by the governor from commission nominees, and periodically stand for election on their records, without specified opponents. Id. at 41-43.

289 See note 288 supra and authorities there cited.

200 See note 286 supra.

201 Duncan v. Louisiana, 88 S. Ct. 1444, 1447 (1968), reversing a conviction for simple assault (characterized as a serious rather than a petty offense because the possible penalty was imprisonment for two years, although the actual sentence was imprisonment for 60 days and a fine of $\$ 150$ ) on the ground that the state constitutional provision foreclosing a jury trial violated due process. Justices Black and Douglas concurred on the ground that the fourteenth amendment incorporates the entire Bill of Rights. Id. at 1454. Justice Fortas, concurring, could not agree "with the implication .. . that we automatically import [to the states] all of the ancillary rules which have been or may hereafter be developed incidental to the right to jury trial in the federal courts. . . . We may well conclude that [some] features of federal jury practice are by no means fundamental - that they are not essential to due process of law ...." Id. at 1459-60. Justices Harlan and Stewart, dissenting, rejected incorporation of the sixth amendment by the fourteenth, and denied that the right to jury trial in criminal cases is "an element of fundamental procedural fairness." Id. at 1467. 
was concerned with safeguards against royally selected judges, as indicated by the Court's quotation from Blackstone:

Our law has . . . placed . . . trial by jury between the liberties of the people and the prerogative of the crown. It was necessary . . . to vest the executive power of the laws in the prince: and yet this power might be dangerous and destructive . . . if exerted without check or control by justices . . . occasionally named by the crown . . . . ${ }^{293}$

"The first Continental Congress," recalls the Court, "objected to trials before judges dependent upon the Crown alone for their salaries and to trials in England for alleged crimes committed in the colonies." 284 "Those who wrote our constitutions knew from history and experience that it was necessary to protect against unfounded criminal charges brought to eliminate enemies and against judges too responsive to the voice of higher authority." 295

The Court also suggests, however, that the jury trial option is necessary to protect against biased, eccentric, or incompetent judges ${ }^{290}$ and perhaps to permit ad hoc departures from rigid or disfavored rules ${ }^{297}$ - purposes relevant to trials before elected as well as permanently appointed judges. Such litigation policies, though vigorously challenged, are generally reflected by state jury trial provisions but do not necessarily underlie the sixth amendment guarantee. The historical context relied upon by the Court supports the view that the federal constitutional purpose is community surveillance of a tenured, sometimes nonlocal, judiciary appointed by the executive-a purpose later implemented in state trials by electoral supervision of local judges. ${ }^{298}$

293 Id., quoting $4 \mathrm{~W}$. Blackstone, Commentaries $* 359-60$.

29488 S. Ct. at 1449.

$295 \mathrm{Id}$. at 1451.

298 "Providing an accused with the right to be tried by a jury of his peers gave him an inestimable sageguard against the corrupt or overzealous prosecutor and against the [compliant], biased, or eccentric judge. ... [T] he jury trial provisions . . reflect . . a reluctance to entrust plenary powers over the life and liberty of the citizen to one judge or to a group of judges." Id. at 1451.

297 "If the defendant preferred the common-sense judgment of a jury to the more tutored but perhaps less sympathetic reaction of a single judge, he was to have it." $I d$. "The most recent and exhaustive study of the jury in criminal cases concluded that ... when juries differ with the result at which the judge would have arrived, it is usually because they are serving some of the very purposes for which they were created and for which they are now employed." Id. at 1451-52, citing H. KALVEN \& H. ZEISEL, The AMERICAN JuRy 4 n.2 (1966).

"A jury may, at times, afford a higher justice by refusing to enforce harsh laws (although it necessarily does so haphazardly, raising the questions whether arbitrary enforcement of harsh laws is better than total enforcement, and whether the jury system is to be defended on the ground that jurors sometimes disobey their oaths)." Id. at 1469 (Harlan, J., dissenting) citing ("See generally") G. WILlIAMs, ThE Proof of GUILT 257-63 (1955); W. Forsyth, History OF TRIAL BY JURY 261 (1872). 
If protection against inadequate judges and overly rigid application of rules is a sixth amendment criminal jury value, it may well be a seventh amendment civil jury value, unless vitiated by the less drastic consequences of noncriminal proceedings. If such protection is not a sixth amendment value, the Court may nevertheless evaluate the jury trial option as essential to fair criminal trials apart from the sixth amendment guarantee, ${ }^{299}$ an evaluation perhaps implicit in the Court's characterization of the criminal jury right as fundamental. Such an evaluation, strongly disputed by Justices Harlan and Stewart and by many commentators, ${ }^{300}$ can more cogently be confined to criminal proceedings when based upon values not attributed to the sixth amendment and therefore less attributable to the seventh.

Uncertainty over the original understanding of the fourteenth amendment's enacters is not surprising. ${ }^{301}$ The purpose of imposing upon the states at least some Bill of Rights restrictions is suggested by the legislative history as well as by the problems of federal-state authority and state oppression of negroes to which the Amendment was directed. $^{302}$ But the fourteenth amendment Congress did not undertake to identify the constitutional goals that would be implemented by application to the states of each Bill of Rights requirement. That issue has remained for Supreme Court resolution.

\section{Social Purpose and Constitutional Values:}

\section{Accommodation and Subordination of Regulatory Goals}

Identification of the values underlying constitutional language is a process of creative integration reflecting judicial sensitivity to community structure, needs, and attitudes. But the identification of relevant constitutional values does not decide the constitutional issue. A regulation that inhibits to some extent constitutionally sheltered activity is not ner se invalid. Constitutional limitations on government do not ahsolutelv proscribe all regulation that places tension on the underlying values. Such limitations are not concisely delineated rules of official behavior; they are generalized descriptions of sheltered areas-areas, such as speech, too encompassing and too indistinct in contour to be totally insulated from regulation that implements other important com-

298 See text accompanying notes 76-90, 104-16 supra, 350-52 infra.

300 See Duncan v. Louisiana, 88 S. Ct. 1444, $1467-70$ (1968) (Harlan and Stewart, JJ., dissenting).

301 See notes 270-71 supra and accompanying text.

302 See authorities cited note 271 supra. 
munity values. ${ }^{303}$ Despite the frequent assumption that a balancing of constitutional and regulatory values is the only alternative to an absolute constitutional standard, ${ }^{303 a}$ these values can be judicially adjusted without the customary balancing that reflects either judicial regulatory preferences or uncritical judicial deference to constitutionally questionable legislative policy. ${ }^{303 b}$

Most regulation of sheltered activity implements community values that are not constitutionally disapproved. A value is constitutionally disapproved when its implementation stultifies implementation of a constitutionally recognized value. If no method of accommodating the two values is available, the former value lacks social purpose and is necessarily subordinated to the latter. Regulatory and constitutional values are accommodated by methods that substantially implement both.

Time, place, and decibel regulation of large public meetings minimizes serious traffic obstruction and noisy intrusion on the privacy of others. Traffic and privacy values are not disapproved by the Constitution. Although communication is restricted to some extent, traffic, privacy, and speech values are accommodated, because the ideas of the participants can be effectively presented in a manner consistent with such regulation. ${ }^{304_{1}^{4}}$ But a regulation forbidding expression of unpopular

303 Justice Black has been the chief judicial protagonist of the position that constitutional limitations are "absolute." For support and criticism of that position see: A. Bickel, The Least Dangerous Branch 93, 96-97 (1962); C. Black, Mr. Justice Black, the Supreme Court, and the Bill of Rights, HARPER's, Feb. 1961 at 63; H. Black, The Bill of Rights, 35 N.Y.U. L. REv. 865 (1960) ; Cahn, Mr. Justice Black and First Amendment "Absolntes": $A$ Public Interview, 37 N.Y.U. L. Rev. 549 (1962); Freund, Mr. Justice Black and the Judicial Function, 14 U.C.L.A. L. Rev. 467 (1967) ; Kalven, Upon Re-reading Mr. Justice Black on the First Amendment, 14 U.C.I.A. L. Rev. 428 (1967). See also P. Kauper, Crvil LIBERTIEs aNd THE Constrtution 114-17 (1962); A. Meirlejohn, Free SpeEch and Its Relation to SElF-Government (1948), reviewed, Chafee, 62 HARv. L. REv. 891 (1949) ; Emerson, Toward a General Theory of the First Amendment, 72 YALE L.J. 877 (1963); Frantz, Is the First Amendment Law?-A Reply to Professor Mendelson, 51 Calif. L. REv. 729 (1963); Frantz, The First Amendment in Balance, 71 YALE L.J. 1424 (1962); Mendelson, On The Meaning of the First Amendment: Absolutes in the Balance, 50 Calif. L. Rev. 821 (1962).

3032 See A. BICKEI, supra note 303, at 84-98; P. KAƯper, C. Black, Emerson, Frantz, Mendelson, supra note 303; Karst, supra note 253.

$303 b$ See text accompanying notes $133,141,165-67$ supra. The "preferred position" sometimes accorded either the first amendment or the entire Bill of Rights primarily constitutes a rebuttable presumption that infringing regulations are invalid. See note 262 sipra and accompanying text; note 321 infra. This presumption at most allocates to the regulatory proponent the burden of persuading the court that the social benefits of the regulation strongly outweigh the detriment resulting from impairment of the constitutional values, an allocation that is psychologically significant only when the Court perceives the balance to be at or near equilibrium. The purpose of the preferredposition presumption is apparently to encourage active judicial balancing, i.e., the "constitutionalization" of judicial regulatory preferences, when a challenged regulation affects civil liberties, political redress being difficult, while preserving restrained judicial balancing, i.e. deference to legislative policy, when economic regulation is challenged. See C. BLACK, supra note 262; Frantz, supra note 303.

304 See cases cited note 196 supra. 
views, when no disorder threatens, is designed to insulate the community from intellectually disturbing or distasteful communications and possible emotional insecurity. That purpose stultifies first amendment speech values; intellectual and emotional tranquility are necessarily subordinated to the effective self-government and imaginative private ordering that result from uninhibited exchange of ideas. ${ }^{305}$

The inclusion of prayers in a public school curriculum reflects solely a religious instruction purpose that contradicts anti-establishment of religion values, concerned with the social divisiveness engendered by governmentally supported propagation of religious doctrine. ${ }^{306}$ Free exercise of religion values are not significantly impaired by exclusion of prayers as long as religious instruction is easily available at home and in church. ${ }^{307}$ But publicly financed transportation for students at church-administered schools implements safety and educational values that are not constitutionally disapproved. ${ }^{308}$ Regulatory purpose and anti-establishment values are accommodated because receipt of the nondoctrinal transportation benefit by taxpaying believers and unbelievers alike minimizes its social divisiveness as a religious aid. ${ }^{309}$

Failure of the regulatory method to implement the ostensible regulatory purpose often indicates that the true purpose of the regulation is constitutionally disapproved. In Griswold the ineffectiveness of the regulatory method to implement the ostensible regulatory purpose ${ }^{310}$

305 See Edwards v. South Carolina, 372 U.S. 229 (1963) ; Kingsley Int'1 Pictures Corp. v. Regents of the Univ. of the State of N.Y., 360 U.S. 684 (1959) ; Joseph Burstyn, Inc. v. Wilson, 343 U.S. 495 (1952); Niemotko v. Maryland, 340 U.S. 268 (1951).

Regulations concerned with threatened disorder, insulting language, obscenity, and defamation implement values that are not constitutionally disapproved; such regulations must be appraised in terms of less intrusive alternatives. See text accompanying notes $319-44$ infra.

For other speech values see note 274 sipra.

308 See Abington School Dist. v. Schempp, 374 U.S. 203 (1963) ; Engel v. Vitale, 370 U.S. 421 (1962); McCollum v. Board of Educ., 333 U.S. 203 (1948). But see Zorach v. Clauson, 343 U.S. 306 (1952). Compare Howe, The Constitutional Question, in Fund FOR THe Republic, Religion aND THE Free Soctety 49, 51-52, 55 (1958), and Giannella, Religions Liberty, Nonestablishment, and Doctrinal Development, 80 HARv. L. Rev. 1381, 1389 (1967), with Choper, Religion in the Public Schools: $A$ Proposed Constitutional Standard, 47 MINN. L. REv. 329, 329-31 (1963). See also Griswold, Absolute Is in the Dark-A Discussion of the Approach of the Supreme Court to Constitutional Questions, 8 UTAB L. REv. 167, 177 (1963) ; Kauper, Prayer, Public Schools and the Supreme Court, 61 MICE. L. REv. 1031, 1046, 1065-66 (1963); Kurland, The Regents' Prayer Case: "Full of Sound and Fury Signifying . . .", 1962 Sup. Cт. Rev. 1, 30; Sutherland, Establishment According to Engel, 76 HARv. L' Rev. 25, 45 (1962).

${ }^{307}$ See Abington School District v. Schempp, 374 U.S. 203, 296-99 (1963) (Brennan, J., concurring).

308 See Everson v. Board of Educ., 330 U.S. 1 (1947). See also Board of Educ. v. Allen, 88 S. Ct. 1983 (1968).

${ }^{309} C f$. authorities quoted in W. LOCKRART, Y. KAMISAR \& J. CHOPER, supra note 137, at 1125-82.

${ }^{310}$ See notes 154, 168, 172 supra and accompanying text. 
suggests that the true purpose of the regulation was to identify as community policy a religious attitude of disapproval toward contraception, a purpose that contradicts anti-establishment values.

Values that are constitutionally preferred for some purposes may be constitutionally subordinated for others. Truth ascertainment values underlie many of the enforcement procedures specified by the Bill of Rights. $^{311}$ But the privacy, antiharassment, and antibrutality values underlying the unreasonable search and seizure protection are stultified by the use of improperly seized evidence to assist in truth ascertainment. ${ }^{312}$ Until an effective way to implement both sets of values is devised, those underlying the search and seizure directive are constitutionally preferred in situations involving such proscribed official conduct. Although prosecutor comment on an accused's failure to testify is designed to facilitate jury evaluation of the evidence, that truth ascertainment goal is subordinated by the self-incrimination clause to a truth ascertainment goal that preserves for the accused the control of his defense. ${ }^{313}$

Competing constitutional and nonconstitutional enforcement values can often be accommodated. Exclusion of in-court identifications based upon police-arranged pretrial confrontations that were not observed by counsel accommodates both the constitutional, assistance of counseltruth ascertainment goal and the nonconstitutional, effective identification-truth ascertainment goal. ${ }^{314}$ And use of compelled driver-intoxication tests ${ }^{315}$ to facilitate truth ascertainment does not significantly impair the privacy, antiharassment, and antibrutality values underlying the search and seizure and self-incrimination protections when the tests are performed by qualified personnel after probable cause for arrest. ${ }^{\mathbf{3 1 0}}$

311 See notes 94-102 supra and accompanying text.

312 See notes 117-19 supra and accompanying text.

313 See note 281 supra.

314 See United States v. Wade, 388 U.S. 218 (1967).

315 The test may be administered over the objection of the accused, Schmerber v. California, 384 U.S. 757 (1966), or may be compelled by driver's license suspension for refusal to submit, specified as a condition to issuance of the license. See CAL. VEAICLE CODE $\$ 13353$ (West 1960). A choice of tests may be offered. Id. The fiction that the imposed condition constitutes consent is needless.

316 See Schmerber v. California, 384 U.S. 757 (1966). See also Breithaupt v. Abram, 352 U.S. 432 (1957).

The self-incrimination-truth ascertainment values that forbid compelled response to police questioning ( see notes 97,102 supra) are not impaired by the use of physical test results because: (1) the accused cannot be coerced, tricked, or induced to respond with an untrue test result; (2) ambiguous or apparently damaging oral replies can be explained by the accused at the trial only at the risk of character impeachment (see note 281 supra); physical tests do not threaten such interference with control of the defense; (3) the prosecution, with its greater resources, is not given the opportunity of tailoring its case to fit information first obtained by questioning the accused (see note 102 supra). Perhaps, however, observation of the testing procedures by counsel is indicated by the truth ascertainment values underlying the assistance of counsel guaranty. See text at note 314 supra. 
A regulation lacks social purpose when constitutionally sheltered activity is significantly restricted for a trivial, though constitutionally permissible, purpose. As indicated by Justice Brandeis, constitutional values cannot be reconciled with substantial regulation of the activities they shelter unless the regulation is designed to avoid "serious," not "trivial," harm. ${ }^{317}$ Judicial identification of trivial purpose and significant restriction involves no more than an appraisal of small inconveniences and marginal restraints. For example, the slight impediment to pedestrian movement caused by leaflet distribution is clearly not the kind of social harm that may provide the occasion for significant speech restriction. But a requirement of substantial space between distributors to facilitate traffic flow does not significantly restrict communication of the message. ${ }^{218}$

\section{Constitutionaliy Preferred Accommodations}

.Constitutional values may be infringed no more than necessary to implement a permissible regulatory purpose; ${ }^{319}$ only the least infringing method is socially useful., 'Speech, for example, is infringed less by time, place, and decibel regulation than by official discretion to grant or withhold meeting permits, though both methods accommodate traffic, privacy, and speech values. ${ }^{320}$

The affirmative recognition accorded sheltered activities gives them constitutional precedence over residual activities shielded solely by the due process-social purpose limitation. Accommodations that restrict residual rather than sheltered activity are thus constitutionally preferred. ${ }^{321}$ This constitutional preference reduces the significance of cost and probably broadens judicial discretion to evaluate effectiveness when alternatives to sheltered-activity regulation are under consideration.

317 Whitney v. California, 274 U.S. 357, 376-78 (1927) (concurring opinion).

318 See Public Utilities Comm'n v. Pollak, 343 U.S. 451 (1952); Jamison v. Texas, 318 U.S. 413 (1943) ; Schneider v. New Jersey, 308 U.S. 147 (1939); Lovell v. City of Griffin, 303 U.S. 444 (1938) ; cf. Adderley v. Florida 385 U.S. 39 (1966). But see Breard v. Alexandria, 341 U.S. 622 (1951); Valentine v. Chrestensen, 316 U.S. 52 (1942).

319 See notes 184-200 supra and accompanying text.

320 See notes 196, 304 supra and accompanying text.

321 Compare references to the "preferred position" of the first amendment, or of the Bill of Rights, that suggest: (1) a "narrower" presumption of constitutionality, or a presumption of unconstitutionality, when a regulation apparently infringes such provisions, see note 262 supra; and (2) that first amendment values are more important than other (or most other) constitutional values, and are therefore to be accorded greater weight. See McKay, The Preference for Freedom, 34 N.Y.U. L. REv. 1182 (1959); cf. note 303b supra and accompanying text. 


\section{Community Payment of Regulatory Costs}

Increased public expenditure, with its implicit restriction on residual activity, is often the constitutionally required alternative to a regulation that significantly restrains sheltered activity. ${ }^{322}$ Speech and public order values are better accommodated by additional police protection for unpopular speakers than by proscription of speech in the presence of hostile listeners. ${ }^{323}$ And the assistance-of-counsel values can be effectively implemented only by public expenditure to provide lawyers for accused indigents. ${ }^{324}$ The cost of increased police protection and of counsel for indigents, though substantial, is constitutionally less intrusive than significant impairment of the constitutional values.

Higher-cost alternatives to sheltered-activity regulation are supported by the fifth amendment inhibition on the taking of private property for public use without just compensation. The provision reflects an antiretroactive deprivation value that encourages productive behavior by augmenting the capacity of each person to benefit from his own efforts and to plan for the future. ${ }^{325}$ It further reflects an equality of taxation value concerned with even-handed assessment of governmental and regulatory costs. ${ }^{326}$ When these values are impaired by a

322 Cf. text accompanying notes 237-38 supra, 328-31 infra.

323 See Edwards v. South Carolina, 372 U.S. 229 (1963) ; Kunz v. New York, 340 U.S. 290,294 (1951); Sellers v. Johnson, 163 F.2d 877, 883 (8th Cir. 1947), cert. denied, 332 U.S. 851 (1948); cf. Terminiello v. Chicago, 337 U.S. 1, 4 (1949). But cf. Feiner v. New York, 340 U.S. 315 (1951); Chaplinsky v. New Hampshire, 315 U.S. 568 (1942).

324 See Gideon v. Wainwright, 372 U.S. 335, 344 (1963).

325 See Michelman, Property, Utility, and Fairness: Comments on the Ethical Foundations of "Just Compensation" Law, 80 HARv. L. REv. 1165, 1210-13 (1967). This value is also reflected by the contract impairment, ex post facto, and bill of attainder clauses, and has long been implemented by the due process limitation. See notes 14, 284-85 supra and accompanying text. In fact, every contract impairment case implicitly presents a compensation clause issue, though judicial perception of that integral relationship has been sporadic. See City of EI Paso v. Simmons, 379 U.S. 497, 533-35 (1965) (Black, J., dissenting); Lichter v. United States, 334 U.S. 742 (1948) ; Lynch v. United States, 292 U.S. 571, 579-80 (1934); cf. FHA v. The Darlington, Inc., 358 U.S. 84 (1958).

326 See Michelman, supra note 325, at 1176-80. See also Sax, Takings and the Police Power, 74 YALE L.J. 36 (1964). For a statement of equality values see note 282 supra.

The graduated income tax does not impair this value if, on the one hand, the quantum of basic fulfillment (see text following note 157 supra) forestalled by payment of each tax dollar diminishes at an accelerated rate as income increases and, on the other, incentive to productivity inhibits governmental leveling of incomes. But see W. Blum \& H. Kalven, The Uneasy Case for Progressive Taxation 21 (1953).

In their book, Professors Blum and Kalven doubt the diminishing utility of money, id. at $22-23,57-60$, a doubt that perhaps disturbs the case for proportionate taxation as well. See id. at 23. But see id. at 42-45. Because the psychological deprivation per tax dollar varies significantly with each taxpayer, rich or poor, no generalized utility curve for money can be constructed. Yet an assumed equivalence of such deprivation to the rich and not-so-rich implies that the psychological distress of a 
socially useful regulation, the clause indicates that community rather than individual payment of regulatory costs is the less intrusive accommodation. ${ }^{327}$

The obligation of government to compensate for regulatory deprivation does not depend upon definitions of "property," "taking," and "public use." The unruly events that pose social problems will not fit mechanical, linguistic pigeonholes." Nor is a "balancing" of private detriment and public benefit meaningful in the absence of standards for appraising the balance. ${ }^{32 \theta}$ Neither definitional nor balancing solutions are workable unless they identify and implement the values underlying the constitutional language.

$\$ 100,000$ taxpayer is twenty times that of a $\$ 5,000$ taxpayer, an implication that seems contrary to experience. The satisfactions of ostentatious consumption are not significantly affected by a progressive tax because social competitors are subject to the same rates. Whatever the psychological distress of individual taxpayers, a probable community consensus recognizes an inverse hierarchy of tax-dollar deprivations that applies not only to income below some uncertain level of minimum subsistence, which Professors Blum and Kalven concede should be tax exempt, id. at 90-91, but to the entire progression of goods and services that accompany increasing wealth.

327 See Griggs v. Allegheny County, 369 U.S. 84, 90 (1962) ; Berman v. Parker, 348 U.S. 26, 36 (1954); United States v. Kansas City Life Ins. Co., 339 U.S. 799 (1950); United States v. Causby, 328 U.S. 256 (1946) ; Panhandle E. Pipeline Co. v. State Hwy. Comm'n, 294 U.S. 613, 622-23 (1935); Pennsylvania Coal Co. v. Mahon, 260 U.S. 393, 416 (1922) ; Chicago, B. \& Q. R.R. v. Chicago, 166 U.S. 226, 236-37 (1897) ; cf. text accompanying notes 237-38, 322-24 sipra. But cf. Goldblatt v. Town of Hempstead, 369 U.S. 590 (1962); Miller v. Schoene, 276 U.S. 272 (1928).

328 As to the scope of "property," "taking," and "public use," compare [1] Pennsylvania Coal Co. v. Mahon, 260 U.S. 393 (1922) (compensation for prohibition of coal mining producing surface subsidence) with Miller v. Schoene, 276 U.S. 272 (1928) (no compensation for destruction of ornamental cedar trees by official order to prevent apple orchard infection with cedar rust); Mugler v. Kansas, 123 U.S. 623 (1887) (no compensation for loss of brewery use pursuant to newly enacted prohibition statute); [2] Panhandle E. Pipeline Co. v. State Hwy. Comm'n, 294 U.S. 613 (1935) (compensation for moving of pipelines to permit highway construction) with Atchison, T.\&S.F. Ry. v. Public Util. Comm'n, 346 U.S. 346 (1953); New Orleans Pub. Service, Inc. v. New Orleans, 281 U.S. 682 (1930) (no compensation for compelled elimination of railroad grade crossings on highways); [3] Griggs v. Allegheny County, 369 U.S. 84 (1962); United States v. Causby, 328 U.S. 256 (1946) (compensation for noise from directly overflying military and commercial planes using nearby military and public service airports) with Euclid v. Ambler Realty Co., 272 U.S. 365 (1926) (no compensation for prospective zoning ordinance limiting land use); [4] Hadacheck v. Sebastian, 239 U.S. 394 (1915) (no compensation for zoning termination of existing industrial use as brickyard causing disturbance to recently developed residential area) with state cases invalidating uncompensated termination by zoning of existing nonconforming uses, collected in 1 A.L.R. 2d 931 (1965) (later case service); 42 A.I.R. 2d 1150 (1955); 9 A.L.R. 2d 1039 (1952); 156 A.L.R. 588 (1945); 124 A.L.R. 538-40 (1940); 86 A.L.R. $684-88$ (1933). See also Berman v. Parker, 348 U.S. 26, 32 (1954), indicating that "public use" is synonymous with social purpose.

${ }^{329}$ See Dunham, Griggs v. Allegheny County in Perspective: Thirty Years of Supreme Court Expropriation Law, 1962 SuPREME COURT REVIEW 63, 73-80. "[C] ]ourts have never been able to develop... a standard more meaningful than balancing the public need against the private cost." Id. at 75. Kratovil \& Harrison, Eminent Donain-Policy and Concept, 42 CALTF. L. Rev. 596, 609 (1954) : “. . . only a difference in degree exists between noncompensable damage to a property owner under the police power and a deprivation of property rights under the power of eminent domain ... [T] o determine whether or not the line... has been crossed, the extent of the diminution of the owner's rights must be weighed against the importance of that diminution to the public." (Footnọtes omitted). 
Application of the compensation clause should turn upon: (a) whether the assessed individual derives a commensurate benefit from the regulatory assessment, (b) whether failure to compensate will seriously disrupt private ordering: could the individual anticipate and adjust for the assessment? were there prior indications of the assessment-indications usually present when the assessed activity is a source of harm? was the risk of such assessment an aspect of a speculation for profit? can the assessed individual recoup from the community through such economic mechanisms as pricing? and (c) whether compensation is an effective alternative: will compensation defeat the regulatory purpose ? $^{330}$ will the added cost of administering compensation require abandonment of the regulatory purpose as socially inefficient? ${ }^{331}$

But a taking with compensation also restricts human activity and infringes the due process-social purpose limitation when the regulatory purpose lacks utility or can be implemented by a less intrusive method..$^{332}$

\section{The Testing of Probably Effective Alternatives}

Evaluation of clear effectiveness ${ }^{333}$ may require experience with the functioning of an alternative, experience unobtainable while the challenged regulation is in effect. When that regulation sharply restricts constitutionally sheltered activity, a court may be justified in setting it aside to permit the testing of a less intrusive alternative whose effectiveness is considered probable.

An alternative regulation cannot be tested without cooperative legislative enactment. Non-formal alternatives may function upon

330 Consider Norman v. Baltimore \& O. R.R., 294 U.S. 240 (1935), sustaining congressional authority to abrogate "payment in gold" clauses in private contracts, and Perry v. United States, 294 U.S. 330 (1935) finding no damage from abrogation of such clauses in government bonds.

331 Compensation allocates but does not increase the social costs of regulation. Administration is an added cost. See Michelman, sitpra note 325 ; cf. Sax, supra note 326 , at 63 :

The rule proposed here is that when economic loss is incurred as a result of government enhancement of its resource position in its enterprise capacity, then compensation is constitutionally required; it is that result which is to be characterized as a taking. But losses, however severe, incurred as a consequence of government acting merely in its arbitral capacity [improvement of the public condition through resolution of conflict within the private sector of society] are to be viewed as a noncompensable exercise of the police power.

The rationale is unclear as to why the compensation clause values are not relevant to "losses, however severe," resulting from government acting "merely" to improve the public condition by regulation of private activity. The distinction between the "enterprise" and "arbitral" functions of government does not appear to resolve effectively the problems presented by the cases at note 328 supra.

332 Cf. Berman v. Parker, 348 U.S. 26 (1954). For the older view that a taking with compensation must be for a public "use," see Missouri Pac. Ry. v. Nebraska, 164 U.S. 403,417 (1896); cases collected in Note, The Public Use Limitation on Eminent Domain: An Advance Requiem, 58 Y ALE L.J. 599 (1949).

333 See text accompanying notes 229-30, 239-48 supra. 
judicial displacement of the challenged regulation. ${ }^{334}$ The ensuing experience with either a formally enacted or non-formal alternative can be evaluated by both institutions. No further institutional action is required if the legislature views the alternative as effective. A later reenactment of the initial regulation should be judicially reversed only when the effectiveness of the alternative has been clearly established by the intervening experience.

When applied, the clear and imminent danger requirement for speech-inhibiting regulation ${ }^{\mathbf{3} 5}$ has facilitated appraisal of community discussion intervening between speech and action as an effective method of interdicting threatened harm. The recent preclusion of a judicial remedy for nonmalicious defamation of public officials permits appraisal of reply in the communications media as an effective, speech-protecting alternative for alleviating such defamation. ${ }^{336}$ The preclusion of recovery for malice as well, urged by three Justices, would permit an appraisal of the reply alternative as a probably effective remedy for all defamation of public officials. ${ }^{337}$

A similar judicial approach to obscenity regulation could provide the opportunity for community appraisal of less intrusive alternatives. First amendment, privacy of thought values that shelter interesting and enjoyable communications ${ }^{338}$ are infringed by proscription of sexually stimulating material, as they are infringed by proscription of material that stimulates joy, sadness, and other emotions, or hunger, thirst, and other drives. "Hard-core" pornography scarcely lacks social importance because it provides sexual gratification. ${ }^{339}$ The social purpose of

334 See text accompanying notes 250-51 supra.

335 See cases cited note 249 supra; Herndon v. Lowry, 301 U.S. 242, 258-59 (1937); Cantwell v. Connecticut, 310 U.S. 296 (1940); Bridges v. California, 314 U.S. 252 (1941) ; Pennekamp v. Florida, 328 U.S. 331, 334 (1946) ; Craig v. Harney, 331 U.S. 367 (1947) ; American Communications Ass'n v. Douds, 339 U.S. 382, 445-53 (1950) (Black, J., dissenting) ; Dennis v. United States, 341 U.S. 494, 584 (1951) (Douglas, J., dissenting) ; Yates v. United States, 354 U.S. 298 (1957); Scales v. United States, 367 U.S. 203, $259-89$ (1961) (Black, Douglas, and Brennan, JJ., dissenting); Noto v. United States, 367 U.S. 290 (1961); Wood v. Georgia, 370 UU.S. 375, 388-89, 393 (1962).

336 New York Times Co. v. Sullivan, 376 U.S. 254 (1964). See note 250 supra.

337376 U.S. at 296-97 (Black \& Douglas, JJ., concurring) ; id. at 304-05 (Goldberg \& Douglas, JJ., concurring); see note 250 supra and accompanying text.

338 See note 274 sipra.

339 See Ginzburg v. United States, 383 U.S. 463, 491-92 (1966) (DoGglas, J., dissenting) ; cf. A Book Named "John Cleland's Memoirs of a Woman of Pleasure" v. Attorney General, 383 U.S. 413, 418 (1966) ; Jacobellis v. Ohio, 378 U.S. 184, 195 (1964). But cf. Mishkin v. New York, 383 U.S. 502, 508-09 (1966); Roth v. United States, 354 U.S. 476, 484 (1957); Manual Enterprises, Inc. v. Day, 370 U.S. 478, 487 (1962) ; Lockhart \& McClure, Obscenity Censorship: The Core Constitutional IssueWhat Is Obscene?, 7 UTAE L. REv. 289, 296-97 (1961); Brief for Respondent, Roth v. United States, 354 U.S. 476 (1957), cited in Lockhart \& McClure, supra, at 295; 
banning material primarily designed to provide sexual gratification, commonly labeled "obscene," is probably to inhibit incitement of antisocial sexual conduct, to avoid mental distress resulting from involuntary exposure to such material, to reduce distortion in the sexual education of children, and to preserve parental control over that education. ${ }^{340}$ The purpose of inhibiting impure or immoral thoughts is constitutionally disapproved because it contradicts first amendment privacy of thought and anti-establishment of religion values. ${ }^{341}$

Empirical studies have neither established nor negated a significant correlation between harmful sexual conduct and voluntary adult exposure to pornography. ${ }^{342}$ Substantial informed opinion suggests slight correlation, because adult sexual inclinations are usually set, the tensions that produce harmful acts are commonly released rather than exacerbated by such exposure, ${ }^{343}$ and its impact is engulfed in a flood of environmental sexual stimulants.

Restraint on the unsolicited display of obscene material and on its distribution to children without parental consent, along with existing criminal sanctions for harmful sexual conduct, is a less intrusive alternative. The effectiveness of that alternative could be better appraised if proscription of voluntary adult exposure were invalidated by a court

Model Penal Code $\$ 207.10$, Comment 6(a), at 20 (Tent. Draft No. 6, 1967). Denial of social importance to the sexual gratification provided by hard-core pornography seems to reflect, in part, a disapproval of masturbation. See Mishkin, supra; Roth, supra; Manual Enterprises, supra; Lockhart \& McClure, supra; Brief for Respondent, supra. The desire of a recipient for some form of sexual gratification from the communication is probably the only intelligible meaning of "prurient interest."

340 See J. Paul \& B. Schwartz, Federal Censorship: Obscenity in the Mall 191-202 (1961) ; Cairns, Paul \& Wishner, Sex Censorship: The Assumptions of AntiObscenity Laws and the Empirical Evidence, 46 MINN. L. REv. 1009, 1034-36 (1962); Emerson, Toward a General Theory of the First Amendment, 72 Y ALE L.J. 877, 937 (1963); Henkin, Morals and the Constitution: The Sin of Obscenity, 63 ColuM. I. REv. 391 (1963); Lockhart \& McClure, Literature, the Law of Obscenity, and the Constitution, 38 Mrns. L. REv. 295, 323-33 (1954) ; Magrath, The Obscenity Cases: Grapes of Roth, 1966 SupREME Court Review 7, 48-56; L. Schwartz, Morals Offenses and the Model Penal Code, 63 Colun. L. Rev. 669, 672-73, 681 (1963) ; Slough \& McAnany, Obscenity and Constitutional Freedom-Part II, 8 ST. LouIs U.L.J. 449, 472-77 (1964). See also $1 \mathrm{Z}$. Chafee, Government and Mass Comamunications 212 (1947).

341 See Kingsley International Pictures Corp. v. Regents of Univ. of N.Y, 360 U.S. 684, 688-89 (1959) ; Roth v. United States, 354 U.S. 476, 509-10 (1957) (D̈ouglas, J., dissenting); id. at 507 (Harlan, J., dissenting in part); Joseph Burstyn, Inc. v. Wilson, 343 U.S. 495, 502, 505 (1952); Model Penal Code $\$ 207.10$ (2), Comment 6(a), at 20 (Tent. Draft No. 6, 1957); Henkin, supra note 340, at 392-95. But cf. Roth v. United States, 354 U.S. 476 (1957). note 340 .

342 See Cairns, Paul \& Wishner, supra note 340, at 1032-36; Magrath, stspra

343 See A Book Named "John Cleland's Memoirs of a Woman of Pleasure" v. Attorney General, 383 U.S. 413, 419 (1966) (Douglas, J., concurring); United States v. Roth, 237 F.2d 796, 815-16 (2d Cir. 1956) (Frank, J., concurring); Roth v. United States, 354 U.S. 476, 509 (1967) (Douglas, J., dissenting); Alpert, Judicial Cemsorship of Obscente Literature, 52 HARv. L. REv. 40, 73-75 (1938); Murphy, The Valuse of Pomography, 10 WAYNE L. REv. 655, 661 (1964). But see Memoirs v. Attorney General, supra, at 452-53 (Clark, J., dissenting), and authorities there cited. 
that considered such proscription probably unnecessary to implement the social purpose. ${ }^{344}$

\section{Competing Constitutional Values}

Competing constitutional values challenge a court to accommodate both rather than subordinate the one that weighs less. Free press values are implemented but impartial jury values are impaired by uninhibited pretrial publicity adverse to a criminal defendant. ${ }^{\mathbf{3 4 5}}$ Judicially supervised postponement of such revelations until trial accommodates both sets of values, because public access to information is not foreclosed but only delayed until the evidence is more reliably disclosed to jurors and to the community by the litigation process. ${ }^{346}$ This accommodation is perhaps indicated by the informed-community value underlying the public trial guaranty of the sixth amendment.

Denial of unemployment compensation to persons who refuse suitable work is designed to limit the public cost of unemployment, encourage productivity, and preclude undeserving claims. Such denial also interferes with the free exercise of religion by a claimant whose faith forbids sabbath labor..$^{347}$ An exception exclusively for Sunday sabbatarians impairs both anti-establishment and free exercise values, while minimizing regulatory infringement. An unrestricted choice by each claimant of a day off impairs the regulatory purpose. An exception for all good faith sabbatarians ${ }^{348}$ preserves free exercise values and

344 See N.Y. PENAL LAw \$ 484-h (McKinney 1965), as antended, id. \$\$235.20-.22 (McKinney 1967), declaring illegal the sale of obscene material, as there defined, to persons under 17 years of age; Ginsberg v. New York, 88 S. Ct. 1274 (1968); The Bookcase, Inc. v. Broderick, is N.Y.2d 71, 77, 271 N.Y.S.2d 947, 953, 218 N.E.2d 668, 672 (1966), appeal dismissed sub nom. Bookcase, Inc. v. Leary, 385 U.S. 12 (1966). See also Jacobellis v. Ohio, 378 U.S. 184, 195 (1964); Butler v. Michigan, 352 U.S. 380,383 (1957).

Cairns, Paul, \& Wishner, supra note 340 , at 1035 , find no significant empirical evidence that sexually stimulating material has a greater impact on adolescents than on adults. Cf. Ginsberg v. New York, supra, at 1281-82; Dibble, Obscenity: A State Quarantine to Protect Children, 39 S. CAL. I. REv. 345 (1966).

345 See, e.g., Sheppard v. Maxwell, 384 U.S. 333, 350-52 (1966) ; Estes v. Texas, 381 U.S. 532, 539-40 (1965); Rideau v. Louisiana, 373 U.S. 723 (1963) ; Irvin v. Dowd, 366 U.S. 717, 728 (1961) ; cf. American BAR Assoctation Project on MrniMum Standards for Crtainal Justice, Standards Relating to FaIR Trial and Free Press (Tent. Draft 1966) ; Special Commitree on Radio, Television, and the Adarinistration of Justice of the Association of the Bar of the City of New YoRk, FREEDOMI OF THE PRESS AND FAIR TRIAI (1967) (generally known as the Medina Report) ; Forer, $A$ Free Press and $A$ Fair Trial, 39 A.B.A.J. 800, 843-44 (1953); Rifkind, When the Press Collides With Justice, 34 J. AM. Jud. Soc'y 46, $47-48$ (1950).

346 Change of venue may not sufficiently mitigate the harm, and numerous reversals seriously impair the administration of criminal justice.

347 See Sherbert v. Verner, 374 U.S. 398 (1963). But cf. Braunfeld v. Brown, 366 U.S. 599 (1961).

348 Good faith sabbatarians are persons whose religious beliefs proscribe labor on their sabbath. Good faith is indicated by an established creed and practice. See Braunfeld v. Brown, 366 U.S. 599, 615 (1961) (Brennan, J., dissenting in part); Giannella, supra note 306 , at $1416-23$. 
seriously impairs neither regulatory nor anti-establishment values; the number of non-Sunday sabbatarians is small, and the effect of the minor advantage they receive is protection of free worship rather than propagation of religious doctrine. ${ }^{349}$

\section{The Natural Law of Adjudication: Judictal Derivation of Due Process-Fatr Trial Values}

The judicial function of identifying constitutionally protected fair trial values recapitulates the judicial process of statutory interpretation and common law development. Constitutionally enumerated protections, like statutes, provide authoritative fair trial policy. The values underlying those protections may be judicially extended, by analogy, to support unenumerated protections, as the policy underlying a statute may be judicially extended to situations beyond the reach of the statutory language. ${ }^{350}$ Other judicially developed protections reflect fair trial values derived from appraisal of the adjudication process, as common law policy reflects values derived from appraisal of the social process.

Judicial authority to derive due process-fair trial values from the adjudication process implies authority to evaluate the comparative utility of adjudication procedures. Such procedures are either rejected as irreconcilable with that process, subordinated to requirements having greater adjudication utility, or accommodated with other necessary requirements. Thus, ascertainment of guilt may sometimes be facilitated by placing the burden of persuasion on the accused, but such a burden is judicially perceived as irreconcilable with a more important truth ascertainment value that minimizes for the accused the risk of adjudication mistakes. ${ }^{351}$ And due process limitations on judicial jurisdiction accommodate or "prioritize" the fair trial values relevant to selection of an appropriate place for adjudication. ${ }^{352}$

\section{Accommodation of Fair Trial and Regulatory Values}

Fair trial values must also be accommodated with the non-fairtrial, regulatory values that are sometimes implemented or affected by litigation procedures. Exclusion of privileged communications ${ }^{353}$ from evidence encourages certain relationships at the expense of truth ascer-

${ }^{349} \mathrm{Cf}$. Giannella, supra note 306 , at 1389 ; W. LockenarT, Y. KaMrISAR, \& J. CHOPER, supra note 137 , at 1182-86.

350 See notes 76-93, 104-16 supra and accompanying text.

351 See notes 84,107 supra and accompanying text.

352 See text accompanying notes 109-16 supra.

353 For example, husband-wife and doctor-patient communications. 
tainment. A forum non conveniens dismissal may result from calendar congestion rather than litigant inconvenience. ${ }^{354}$ Although allocation of judicial jurisdiction generally reflects fair place-of-trial objectives, ${ }^{355}$ the exercise of such jurisdiction over a nonresident may permit resolution of the dispute in accordance with forum rather than non-forum policy. ${ }^{856}$

The Supreme Court has moved toward an accommodation of fair venue and regulatory values by acknowledging that forum interest in the application of its policy is relevant to judicial jurisdiction. ${ }^{357}$ Usually that interest reinforces such place-of-trial values as convenience of a litigant residing in the forum and optimal access to evidence of disputed forum events. ${ }^{353}$ But when fair venue values do not support the jurisdiction of an interested state, its regulatory policies may be jeopardized. And when such values support adjudication in two or more states, the regulatory policy may vary with the forum.

Venue and regulatory values may be accommodated in such situations by choice-of-law doctrine that distinguishes authentic from illusory state regulatory interests ${ }^{350}$ and identifies the distinctive values relevant to a choice between competing interests, as well as by perceptive application of the constitutional controls on choice of law: the due process-social purpose limitation that directs the forum to apply the dispute-resolving policy of a state with an interest in that application; ${ }^{380}$ the equal protection values disapproving a distinction between litigants that implements no socially useful purpose; ${ }^{\mathbf{3 6 1}}$ the privileges and immunities-reciprocity value that disapproves dispute-resolving distinctions based solely upon the fact of a difference in litigant residence; ${ }^{362}$ the predictability-antiretroactivity values of the eminent domain, impairment of contracts, ex post facto, and bill of attainder clauses that protect expectations and encourage useful activity; ${ }^{363}$ and

354 See Gulf Oil Co. v. Gilbert, 330 U.S. 501 (1947); cf. First Natl Bank, Ex'r v. United Air Lines, Inc., 342 U.S. 396 (1952) ; Hughes v. Fetter, 341 U.S. 609 (1951). Calendar congestion relates to public cost values.

365 See text accompanying notes $109-16$ supra.

356 See text accompanying notes 179-83 supra.

357 See McGee v. International Life Ins. Co., 355 U.S. 220 (1957) ; Mullane v. Central Hanover Bank \& Trust Co., 339 U.S. 306 (1950) ; Estin v. Estin, 334 U.S. 541 (1948); International Shoe Co. v. Washington, 326 U.S. 310 (1945); Williams v. North Carolina, 317 U.S. 287 (1942) ; Henry L. Doherty \& Co. v. Goodman, 294 U.S. 623 (1935) ; Blackmer v. United States, 284 U.S. 421 (1932) ; Hess v. Pawloski, 274

U.S. 352 (1927). But see Hanson v. Denckla, 357 U.S. 235 (1958).

358 Cases cited note 357 supra.

359 See text accompanying notes $179-83$ supra.

380 Id.

361 See note 282 sipra.

362 See, e.g., Toomer v. Witsell, 334 U.S. 385 (1948) ; Blake v. McClung, 172 U.S. 239 (1898); Currie \& Schreter, Unconstitntional Discrimination in the Conflict of Lazes: Privileges and Immunities, 69 Yale L.J. 1323 (1960) ; cf. Hess v. Pawloski, 274 U.S. 352 (1927).

363 See notes $14,283-85$ supra and accompanying text 
the interstate respect and reciprocity values of the full faith and credit directive that suggest an accommodation of competing state regulatory interests when possible. ${ }^{364}$

\section{Reprise: The Social Purpose and Fair Trial Functions of Due Process}

A due process clause that confines governmental regulation to the least intrusive methods of implementing recognizable community values is consistent with a constitutional plan of written limitations, judicially construed. The goal selection implicit in judicial balancing of regulatory benefits against impairment of natural law values departs from the frame of reference established by the Constitution, weakens it as a symbol of common goals, and inhibits the tentative acceptance of constitutional decisions so important to their social evaluation. Rejection of judicially disfavored legislative goals need not result from judicial comparison of regulatory purpose with recognizable community values nor from judicial appraisal of the restrictiveness, effectiveness, and cost of formal and non-formal alternative methods. That process involves, rather, a collaborative formulation of methods for accommodating legislative goals with individual autonomy.

A due process-social purpose limitation integrates constitutional restraints on federal and on state governments by transposing these restraints when underlying values are thereby implemented. Those values shape for both governments the contours of social purpose and its implementation. But transposition of restraints is not automatic. The values underlying a restraint on one government may not be relevant to the institutional structure of the other or may be effectively implemented by that structure in a different way.

Constitutional values negate the utility of regulatory purposes that contradict them and of regulatory methods that unnecessarily impair them to implement permissible purposes. A method that restricts activity shielded solely by the due process-social purpose limitation is a less intrusive accommodation of constitutional and regulatory values than a method that restricts affirmatively sheltered activity. Consequently, higher cost alternatives, with their implicit restriction on residual activity, are often constitutionally preferred to regulation of

${ }^{364}$ See Crider v. Zurich Ins. Co., 380 U.S. 39 (1965); Clay v. Sun Ins. Office, Ltd., 377 U.S. 179 (1964); Carroll v. Lanza, 349 U.S. 408 (1955); Watson v. Employers Liab. Assurance Corp., 348 U.S. 66 (1954) ; First Nat'1 Bank v. United Air Lines, Inc., 342 U.S. 396 (1952) ; Hughes v. Fetter, 341 U.S. 609 (1951) ; Industrial Comm'n v. McCartin, 330 U.S. 622 (1947) ; Pacific Employers Ins. Co. v. Industrial Accident Comm'n, 306 U.S. 493 (1939); Milwaukee County v. M. E. White Co., 296 U.S. 268 (1935); Alaska Packers Ass'n v. Industrial Accident Comm'n, 294 U.S. 532 (1935) ; Fauntleroy v. Lum, 210 U.S. 230 (1908). 
sheltered activity - a preference supported by the compensation clause of the fifth amendment; and judicial negation of sheltered activity regulation may sometimes be appropriate to facilitate social testing of probably effective, less intrusive alternatives. Competing constitutional values call for an accommodation-not a subordination of the "lighter" one.

Judicial litigation expertise and the linguistic, historical, and functional connotations of "due process" support judicial authority to derive from the adjudication process constitutionally unspecified fair trial requisites reflecting truth ascertainment and expeditious decision values. Bill of Rights procedures, like statutes, provide authoritative fair trial policy that may be extended to nonspecified protections by analogy. Further requirements are derived from the adjudication process as common law is derived from community structure and needs.

But fair trial values must be accommodated with the constitutionally permissible non-fair-trial purposes implemented by some litigation procedures. Thus, jurisdictional and choice-of-law doctrine ought to accommodate fair place-of-trial values and the conduct-regulating policies that may vary with the forum.

Constitutional values are not static. They evolve in response to changing social conditions. Though "fewer and fewer relevantly decisive choices are to be divined out of the tradition of our founding," 365 human needs and problems of social adjustment have not so radically altered in 180 years that the constitutional verbalizations are obsolete. Those verbalizations are continuously reviewed and reinterpreted by judicial articulation and community evaluation of their dispute-resolving implications. Those verbalizations will continue to provide an integrative, associational structure until they no longer suggest values that are relevant to the demands of the physical and social environment.

365 A. BICKEL, supra note 176 , at 39 . 